\title{
Verging on the polemical. Towards an interdisciplinary approach to medieval religious polemic
}

\author{
Sita Steckel*
}

The present article attempts to take stock of the different definitions and connotations of the concept of religious "polemic « in order to encourage a more interdisciplinary debate on this topic. It argues that the interdisciplinary research fields engaging with religious polemics could generate important historical perspectives on current conflict cultures, and appear to be on the verge of an expansion of the horizon towards the global, connecting an extant, highly active research field on religious encounter in the Euro-Mediterranean area to the study of Asia and Africa. To be able to realize an integrative perspective and to write a comparative and entangled history of religious polemics, it seems necessary to reflect on the differences and gaps marking the overlapping research fields. The article therefore offers a brief historiographical sketch concerning the concept of "polemics «, and then offers a preliminary list of constituents or dimensions of the polemical which have been highlighted in the different research fields. In a concluding section, case studies from the accompanying contributions in this volume furnish examples on possible further perspectives, with an emphasis on non-traditional approaches cutting across established research fields.

Keywords: Religious polemics, inter-religious contact, intra-religious conflicts, medieval Judaism, medieval Latin Christianity, medieval Islam, history of Medieval Studies.

\section{Introduction: The problems and potentials of an interdisciplinary approach to religious polemics}

The study of religious polemics remains a highly active subfield of the study of religion, especially in research concerning the medieval Euro-Mediterranean area. Given the prominence of hate speech and religion-based stereotyping today, the relevance and urgency of this topic hardly need to be stressed. Engaging with religious and cultural conflicts and their polemical fallout in a long-term perspective provides us with a unique opportunity to reflect on the dynamics of public debate evolving in different historical societies, including our own present. Within this horizon - which implies a focus on the cultures of debate and conflict visible in polemical exchanges, rather than on their specific religious content - it seems especially

* Correspondence details: Junior Professor Dr. phil. Sita Steckel, Historisches Seminar, Westfälische WilhelmsUniversität Münster, Domplatz 20-22, D-48145 Münster, Deutschland. Email: Sita.steckel@uni-muenster.de. The present thematic section includes papers which originated in sessions of IMC Leeds 2016 and 2017, and the author would like to thank all participants and moderators of the sessions, including Stephanie Kluge. A brief discussion of the articles is offered in the concluding section of the present text. 
important to strengthen emerging interdisciplinary perspectives. On the one hand, this can help to intensify the exchange between pre-modernists and modernists engaging with current political cultures. ${ }^{1}$ On the other, it contributes to an emerging global perspective on the connections and entanglements of religious polemics in different areas, such as Europe and the Mediterranean, the Near and Middle East, Africa and Asia. ${ }^{2}$

Given these imperatives, it is highly welcome that several recent publications have provided new interdisciplinary impulses to the study of religious polemic, juxtaposing historical cases from different contexts and rethinking the theoretical and methodological underpinnings of the field. ${ }^{3}$ But we nevertheless face some conceptual issues, especially in the understanding of the varied and complex phenomenon of religious polemics itself. As Hermann Stauffer noted in 2003, we must operate without a medieval terminology of the "polemical«, as the term only came into use from the seventeenth century onwards, and today acts as an umbrella for several different pre-modern traditions. Instead of a clear modern definition, we also deal with several, partially overlapping ones. ${ }^{4}$ As will be discussed in detail below, "polemic « may be understood very broadly to describe any form of controversy. It may be understood more specifically to denote illegitimate, transgressive argumentation, or it may simply be a shorthand for forms of disparagement and cultural devaluation. ${ }^{5}$ This polyvalence of the term "polemics" appears especially problematic for interdisciplinary research.

As even a superficial analysis shows, the heterogeneous research field of pre-modern religious polemics is indeed characterized by many faultlines. Primarily, these mirror the traditional geographical and chronological subdivisions of academic research, which separate Europe from Asia and other regions, and (at least within European historical studies) the medieval from the (early) modern. In a marked process of interdisciplinary convergence in the last three decades, a highly integrated research field centred on religious encounters between Judaism, Christianity, and Islam in the Euro-Mediterranean area has developed. As only a few regions actually hosted prolonged three-way religious exchange, however (and as academic departments usually favour the study of one religion in its wider contexts), many of the relevant studies have actually devoted themselves to investigating dyadic relationships

1 See, e.g., the recently established Sonderforschungsbereich 1285 "Invectivity. Constellations and Dynamics of Disparagement«, Technische Universität Dresden, at www.tu-dresden.de/gsw/sfb1285?set_language=en (accessed 21.01.2018)

2 See, e.g., the important remarks by Palumbo, From Constantine the Great to Emperor Wu. A connected history of polemics also forms part of the ongoing ERC research project »Jews and Christians in the East: Strategies of Interaction between the Mediterranean and the Indian Ocean«, led by Alexandra Cuffel, Bochum, see www.jewseast. org (accessed 21.01.2018).

3 See especially Sère, Régimes de polémicité; Suerbaum et al., Polemics; Azoulay and Boucheron, Le mot qui tue; Bouhaik-Gironès et. al., Usages et strategies polémiques. An important starting point for the study of religious polemics is still offered by Hettema and Van der Kooij, Religious Polemics in Context.

4 Stauffer, Polemik, 1403.

5 See section 2 below. 
- primarily, those of Christians and Jews, ${ }^{6}$ Christians and Muslims, ${ }^{7}$ and Muslims and Jews. ${ }^{8}$ A handful of other historical confrontations also generated research traditions on medieval religious polemic, for example the exchanges between the Byzantine Greek Orthodox Church and other churches, dissenters, and religions. ${ }^{9}$ More recently, the mainstream of Medieval Studies has begun to acknowledge the complex exchanges between Eastern Christianities, Islam, Zoroastrianism, and other religions, bridging the distance from Byzantium across Syria towards India and China, or from the Middle East towards Africa. ${ }^{10} \mathrm{~A}$ similar picture presents itself for Asian religions, only rarely studied in connection with Medieval Studies but beginning to come into the ambit of comparative and connected history-based approaches. In this field, research often revolves around particular religions such as Buddhism and Taoism and their relationships to other larger traditions. ${ }^{11}$ More or less in a category of its own, research on medieval heresies and heretical movements or related boundary concepts has a long and distinguished tradition, ${ }^{12}$ not only in the study of Christianity, ${ }^{13}$ but also of Judaism ${ }^{14}$

6 See, e.g., (with references to further literature) Abulafia, Christian-Jewish Relations; Baumgarten and Galinski, Jews and Christians in Thirteenth-Century France; Baumgarten et. al., Entangled Histories; Berger, Persecution, Polemic, and Dialogue; Blumenkranz, Auteurs Chrétiens latins; Bonfil et. al., Jews in Byzantium; Carlebach and Schacter, New Perspectives on Jewish-Christian Relations; Chazan, From Anti-Judaism to Anti-Semitism; Cluse, Europas Juden im Mittelalter; Cohen, Living Letters of the Law; Dahan, Christian Polemic; Lasker, Jewish Philosophical Polemics; Trautner-Kromann, Shield and Sword; Yuval, Zwei Völker in deinem Leib.

7 See, e.g., (with references to further literature) Bechmann et. al., Islam im kulturellen Gedächtnis; Burman, Religious Polemic; Conklin Akbari, Idols in the East; Di Cesare, Pseudo-Historical Image of the Prophet; Samir and Nielsen, Christian Arabic Apologetics; Tolan, Saracens; Tolan, Sons of Ishmael; Tolan et. al., Europe and the Islamic World; König, Arabic-Islamic Views; and cf. the first five volumes of Thomas et. al., Christian-Muslim Relations; Tischler and Fidora, Christlicher Norden, Muslimischer Süden.

8 See, e.g., (with references to further literature) Conermann, Muslim-Jewish Relations; Cohen, Middle Ages; Friedmann, Tolerance and Coercion in Islam; Lazarus-Yafeh, Intertwined Worlds; Frank, Jews of Medieval Islam. For a study of cross-cultural views of Islam, see, e.g., Hoyland, Muslims and Others.

9 See, e.g., Beck, Kirche und theologische Literatur; Bonfil et. al., Jews in Byzantium; Bucossi, Dialogues and Anthologies of the Sacred Arsenal; Kolbaba, Byzantine Lists; Rigo and Ermilov, Heresy and Orthodoxy in Byzantium.

10 See, e.g., (with references to further literature) Weltecke, Space, Entanglement and Decentralization; Marx et. al., Östliches Christentum; Pogossian, Conceptual Frontier; Ruani, Controverses religieuses en syriaque; Shaked, Dualism in Transformation; Sims-Williams, Some Reflections on Zoroastrianism; Galík and Slobodník, Eastern Christianity, Judaism and Islam; Malek and Hofrichter, Jingjiao; Tang and Winkler, From the Oxus River. On medieval religious encounter in Africa, see e.g. Dege-Müller, Between Heretics and Jews; or the forthcoming dissertation Verena Krebs, Windows onto the World: Culture Contact and Western Christian Art in Ethiopia, 1402-1543.

11 See (with further references to the literature) Palumbo, From Constantine the Great to Emperor Wu; Zürcher, Buddhist Conquest of China, 254-320; Kohn, Laughing at the Tao; Gorisse, Taste of the Mango; Liu and Shek, Heterodoxy in Late Imperial China; Baskind, Christian-Buddhist Polemics; Höckelmann, Antiklerikalismus und Exklusionsrhetorik; Hureau, Apparition de thèmes anticléricaux.

12 In a transculturally comparative perspective, see Ames, Medieval Heresies; Henderson, Construction of Orthodoxy and Heresy.

13 See, e.g., (with references to the further literature) Iricinschi and Zellentin, Heresy and Identity; Sackville, Heresy and Heretics; Simpson and Roach (eds.), Heresy and the Making of European Culture; Lambert, Medieval Heresy; Laursen et. al., Heresy in Transition; Lourdaux and Verhelst, Concept of Heresy; Van Dussen and Soukup (eds.), Religious Controversy in Europe.

14 See, e.g., Rustow, Heresy and the Politics of Community; Rustow, Karaites Real and Imagined; Diamond, Converts, Heretics and Lepers. 
and Islam. ${ }^{15}$ Because of practical and linguistic barriers, however, many of these fields have developed their own approaches to polemics, providing new definitions and typologies geared towards the study of particular traditions, such as Christian-Jewish polemical exchange. ${ }^{16}$

A closer look also shows other faultlines on the research field. As studies investigating religious polemics were often primarily interested in the phenomenon of religious encounter, sources which appeared to document such encounter best - inter-religious disputations, dialogues and legal sources - have drawn most interest. ${ }^{17}$ This has produced many important scholarly editions and studies of the prime textual witnesses to religious encounters over the last decades. As the medieval centuries had no explicit concept of "polemic", and therefore no textual genres clearly defined as such, however, instances of discourse we call polemical were in many cases spread much further into different genres and discourses than just the classical formats of dialogues and disputations. But texts only containing brief polemical passages, or genres such as, for example, satires about religious elites, have often remained disconnected from other relevant research.

An even more important faultline concerns the divisions between inter-faith or inter-religious polemic and intra-religious polemic (as well as extra-religious polemic ${ }^{18}$ ). As the medieval centuries had different, surprisingly dynamic concepts of the phenomena we call "religion ${ }_{19}^{19}$ the modern division between inter-religious and intra-religious polemic - and instinctual focus on encounter classed as »inter-religious « according to modern views - appears quite problematic. ${ }^{20}$ We know that historical taxonomies of religion, such as the ones current in medieval Christianity, typically show no stable separations between groups we understand as distinct religions (like Judaism or Islam), as intra-religious movements (heresies or religious orders) or finally as other practices involving the sacred (such as sorcery). ${ }^{21}$ Pioneers like Max Weber or the German medieval historian Herbert Grundmann therefore recommended a connected perspective on different religious experts. ${ }^{22}$ But except for some recent studies, such as Hans-Werner Goetz's study of the early and high medieval Christian

15 Adang et. al., Accusations of Unbelief in Medieval Islam; Fierro, Orthodoxy and Heresy in Islam; Ess, Der Eine und das Andere; on the problems of a cross-cultural concept of heresy, see, e.g., Wilson, The Failure of Nomenclature.

16 See, e.g., the typologies of Christian-Jewish polemics discussed below at notes 97 and 165 .

17 See, e.g., Lutz-Bachmann and Fidora, Juden, Christen und Muslime; Abulafia, Christians and Jews in Dispute; Limor, Disputationen; Lewis and Niewöhner, Religionsgespräche im Mittelalter; Yuval and Ben-Shalom (eds.), Conflict and Religious Conversation.

18 On this distinction, see Dascal, On the Uses of Argumentative Reason, 9-13.

19 On the concept of religion during the medieval centuries, see now Weltecke, Religion vor der >Religion<, with references; for late Antiquity and the modern period, see also Barton and Boyarin, Imagine No Religion; Nongbri, Before Religion.

20 As observed by Wiegers, Fuzzy Categories, 745, publications such as the article on religious polemics in the 2005 Encyclopedia of Religion (Berger et. al., Polemics) focus on inter-religious polemics as a matter of course; according to the bibliography assembled in Snoek, Religious Polemics in Context, it is the most active field.

21 An interesting case in point is the inquisitor's handbook authored by the Dominican friar Bernard Gui ( $\dagger$ 1331), Practica inquisitionis, ed. Douais.

22 On Max Weber's approach (studying ideal types of religious actors like priests, prophets and sorcerers in conjunction), see the take by Bourdieu, Genèse et structure du champ réligieux; and cf. Grundmann, Religious Movements in the Middle Ages. 
views of Pagans, Jews, Muslims, heretics and Orthodox Christianity, ${ }^{23}$ most research takes place within a framework separating polemics between Christians, Muslims, and Jews (or other inter-religious constellations) from polemics concerning heresy, and finally from polemical discourses labelled anticlericalism or satire. ${ }^{24}$ Several recent contributions have made the case for the bridging of this divide, but much of the practical work of connecting the separate research fields still remains to be done. ${ }^{25}$

If we hope to discuss the many diverse but related forms of medieval religious polemics in a connected perspective, or to follow the spread of polemical arguments and rhetorical strategies into non-polemical genres within different pre-modern societies, the current, fairly diffuse understanding of religious polemic must become a hindrance. The term needs to be clarified and differentiated - aiming at an operationalization which is broad enough to encompass quite different cultural forms of polemics, but precise enough to allow exchange about significant differences and similarities.

Recent publications have repeatedly offered new overviews and definitions of "polemic", with or without connection to religion, and have offered several clear and at times compact definitions. ${ }^{26}$ As I suspect, however, we will probably not attain the necessary broad yet precise approach to the phenomenon of religious polemics by reducing extant differences in perspective to one clear solution. Such definitions will always favour one type or genre of polemics over another. If we hope to enable more interdisciplinarity, it seems more promising to compile and compare the different elements which have been highlighted as central for religious polemics. Building on a differentiated list of different elements or dimensions of polemics, we might then work towards an open, extendable morphology of different forms of polemical discourse, which can be engaged with and added to by different disciplinary perspectives.

The present article attempts to offer first observations in this direction. Given the sheer range and complexity of the field, it is clear that its view must necessarily be narrow, as well as uneven. The discussion presented here cannot but be influenced by its author's personal interests, namely those of a historian interested in medieval Latin Christianity and intraChristian polemics. The following observations are very obviously restricted in regional scope by the academic background familiar to me, that of the study of the Euro-Mediterranean area and indeed mostly of western Europe. They are to be understood as preliminary, especially in the bibliography - but the article is intended as an express invitation to specialists in other areas and disciplines to engage with this limited view. It begins with a brief overview of three typical connotations of «religious polemics « and the different research interests which have been connected to their study within European academic settings. It then presents an analysis of current definitions of religious "polemic " and an exploration of their constituent elements, which also comments on the state of research and raises potential questions where

23 Goetz, Wahrnehmung anderer Religionen.

24 On anticlericalism and satire, see, e.g., Dykema and Oberman, Anticlericalism in Late Medieval and Early Modern Europe; Höckelmann, Antiklerikalismus und Exklusionsrhetorik; Hureau, Apparition de thèmes anticléricales; on satire, see, e.g., McGuire, Anticlerical Invective; Steckel, Satirical Depictions of Monastic Life.

25 See Jaspert, Communicating Vessels; Weltecke, Space, Entanglement, and Decentralization; Pietsch and Steckel, New Religious Movements before Modernity.

26 One of the best current short definitions is Southcombe et. al., Introduction, 6. 
this seems appropriate. In a third, concluding part, the article briefly explores how a more differentiated and interdisciplinary approach towards religious polemics might broaden the field of research of Latin Christian polemics, suggesting that a more dynamic understanding would allow us better access to discourses which only "verge on the polemical«, and to the complex but important relationship between inter-religious and intra-religious polemics.

\section{Connotations of "religious polemics" within European medieval studies: a sketch}

So far, no in-depth studies of the modern historiography concerning itself with religious polemics seem to be at hand ${ }^{27}$ - and any such studies would have to deal with a complex, by tradition interdisciplinary field. Still, an analysis of recent overviews and encyclopedia articles suggests that we can pragmatically distinguish three main emphases in the understanding of "polemics «. ${ }^{28}$ These different approaches appear to derive from distinct (if overlapping) contexts and diverging scholarly intentions over the last decades and even centuries, which may be sketched out very briefly here to give an impression of the contours of the related fields. This brief tour d'horizon will also serve to contextualize the diverging definitions of polemic discussed in the following section.

The most specialized fields of research, which apply historical, philological, philosophical or theological analysis to inter-religious encounter, often appear to use the term "religious polemic « in a fairly neutral manner, taking it to denote forms of religious controversy. ${ }^{29}$ Scholars working in the relevant fields often refer to the textual traditions of inter-religious dialogic texts resulting from historical exchanges, i.e. to polemics as constituted by specific textual genres. ${ }^{30}$ Though far removed from these roots by now, this approach ultimately appears to derive from the very heyday of religious polemics in Europe, the seventeenth and eighteenth centuries, when the theological faculties and the overarching imagined community of intellectuals, the Respublica Litteraria, developed an elaborate culture of confessionallyoriented theological polemics, which eventually also influenced the debate culture of politics, art and literature..$^{31}$ In this cultural constellation, the term "polemic «, first appearing during the seventeenth century, eventually came to describe an accepted academic sub-discipline, labelled theologia polemica. ${ }^{32}$ Together with its counterpart, apologetics, ${ }^{33}$ this polemical theology was considered a legitimate scholarly pursuit, and the term "polemics" could therefore be used without devaluing overtones. In contrast to later, narrower definitions of

27 But see the bibliographie raisonnée offered by Snoek, Religious Polemics in Context. Bibliographies on particular polemical traditions are listed in Berger et. al., Polemics.

28 The following sections 2 and 3 draw strongly on the overviews by Sère, Introduction; Southcombe et. al., Introduction; Hettema and Van der Kooj, Introduction. Among encyclopedia articles and shorter essays, see Stauffer, Polemik; Cancik, Apologetik/Polemik; Stenzel, Rhetorischer Manichäismus.

29 See, e.g,. Stauffer, Polemik, 1403.

30 See the literature at n. 17 above. Many dedicated studies also include dialogic polemics taking other forms, such as letters or sermons, see, e.g., Trautner-Kromann, Shield and Sword, 5-10.

31 See, e.g., Bremer and Spoerhase, Gelehrte Polemik. Intellektuelle Konfliktverschärfungen; Bremer and Spoerhase (eds.), "Theologisch-polemisch-poetische Sachen".

32 See Stauffer, Polemik, 1407-1408 and, e.g., Pietsch, Isaac de la Peyrère, 38.

33 For a discussion of the possible dimensions of apologetics, see Krech and Schwartz, Religious Apologetics. 
polemics, no connotation of unscholarly or illegitimate argumentation was implied. Even today, we thus find Opera omnia editions of celebrated medieval authors, such as Thomas Aquinas or Jan Hus, containing volumes of their Opera polemica, simply denoting their treatises on controversial subjects. ${ }^{34}$ Though modern research typically dropped the confessional or religious positioning inherent in historical theologia polemica, it has, in part, preserved the broad, open understanding, which simply defines polemics as engagement between different religious groups.

A second, much more critical understanding of the term has more recent connotations but can equally be traced back to the confessionalized landscapes of early modern Europe. ${ }^{35}$ Once confessional divisions within Europe had fully settled during the seventeenth century, controversial debate lost much of its usefulness. Many theologians, now often writing from institutionally secured positions, came to prefer irenical strategies of argumentation instead, and derailed opponents' attacks by accusing them of illegitimate and unscholarly argumentation. ${ }^{36}$ This ideal also drew on values established within the Respublica Litteraria, such as impartiality and fair rules of engagement. ${ }^{37}$ Such normative ideals of regulated scholarly debate were eventually taken up within the realms of politics, art and literature, where a lively style of polemical debate had established itself by the eighteenth century. But they gained decisive weight during the professionalization, "scientification " and institutional differentiation of the European universities during the nineteenth century: scholars and scientists now aspired to form a separate and independent, "objective" societal sphere, forcing a divestment from the spheres of religious/confessional, literary and political debate. ${ }^{38}$ This aspirational ideal of objectivity implied that debates should focus on their controversial issues as objects of analysis, and not treat them as bones of contention in a fight between two or more actors already divided by political, religious or personal conflict. ${ }^{39}$ The "scientific « and "polemical« thus had to part ways, and scholarly identity-building eventually produced a strong preference for analytical and strictly unemotional argumentation and devaluation of persuasive rhetoric. During the twentieth century and especially after the Second World War, this idea was then reappropriated for the political sphere by thinkers intent on the establishment of a democratic debate culture. Public intellectuals as different as Jürgen Habermas and Michel Foucault postulated that (political, but also scholarly) debate should be located within its own deliberative sphere, free and distinct from the power relations and social pressures of society. ${ }^{40}$ Foucault famously attacked polemical engagement in an interview passage which was itself highly polemical. He criticized polemic as a form of argumentation transgressing the limits of open-ended scholarly debate, as its participants attempted to illicitly dominate the sphere of debate. ${ }^{41}$

34 See the list of works of Aquinas at www.corpusthomisticum.org/iopera.html (accessed 22.12.2017); Jan Hus, Magistri Iohannis Hus Polemica, ed. Eršil et al.

35 Cf. Stauffer, Polemik, 1407-1408; Bremer and Spoerhase, Rhetorische Rücksichtslosigkeit.

36 See, e.g., Hirschi, Piraten der Gelehrtenrepublik; Garloff, Irenik, Gelehrsamkeit und Politik.

37 See, e.g., Murphy and Traninger, Emergence of Impartiality.

38 See generally Rüegg, Universities; for the relation of universities and the public sphere Ash, Wissenschaft(en) und Öffentlichkeit(en).

39 See Daston and Galison, Objectivity; Murphy and Traninger, Emergence of Impartiality.

40 See, e.g., Love, Foucault and Habermas; Lubenow, Public Sphere and Deliberative Democracy. On ancient and medieval ideas of free speech, see Van Renswoude and Baumgartner, Censorship, Free Speech and Religion.

41 Foucault, Polemics, Politics and Problematizations, 112. 
This critical view of polemics as illicit argumentation had a strong influence on modern research, as well as the popular usage of the term polemic. Though this critical view did not affect the study of inter-religious polemics deeply, its influence can be felt indirectly in some fields of Medieval Studies, for example the study of some intra-Christian polemics, ${ }^{42}$ where aggressive rhetoric was treated as an embarrassment and separated from scholarly argumentation. More generally, the modern ideal of impartial, open debate exerted influence on research concerning medieval debate culture and learning. Seen in hindsight, this modern ideal attached itself very easily to research perspectives organized along narratives of modernization, prominent within the subfields of medieval intellectual history during the 1960s, 70 s and 8os, which focused on the alleged medieval origins of modern rationality and scientific thought, or on "medieval humanism $\aleph^{43}$ as for example works by Sir Richard W. Southern, a strong proponent of modernization narratives who was to become the doyen of the anglophone intellectual history of the western European High Middle Ages. In his early study of Western images of Islam, Southern argued that medieval Christian perceptions of Islam might not have accepted or even understood Islam. But he still postulated that Western views grew more accurate and rational during the later Middle Ages, asserting that »the statement of the problem became more complex, more rational, and more related to experience ${ }^{44}[\ldots]$.. In this and in similar studies, it was, of course, not denied that Christian authors engaged in polemics with their religious opponents - but within a narrative arc focusing on progress towards modernity, instances of polemics were hardly ever analysed in any depth or given much prominence. This trajectory was soon criticized, which leads us to a third, almost diametrically opposed understanding of polemics which is very common in the youngest layer of research.

The background of this third, current understanding of the polemical is broad and interdisciplinary. Overall, it appears to have been shaped by postmodern and postcolonial perspectives on cultural identities, cultural hierarchies, and the violence underpinning them, a complex of issues which has proved highly relevant and indeed transformative for Medieval Studies ${ }^{45}$ Research fields influenced by these questions were not necessarily focused on religious polemics, but often made use of the term "polemic/polemical« to denote disparagement or aggressive, degrading speech, linked to concepts of intellectual violence such as those studied by Judith Butler's Excitable Speech, but also to various practices of cultural "othering" enabling physical violence. ${ }^{46}$

42 For an example, see Steckel, Une querelle des theologiens.

43 The pioneering study is Southern, Medieval Humanism, but see also his later Scholastic Humanism. Other perspectives insisted on the scientific nature of medieval thought (see, e.g., the reconstruction of Marie-Dominique Chenu's approach in Donneaud, Histoire d'une histoire) or refer to the Enlightenment, like Flasch and Jeck, Licht der Vernunft.

44 Southern, Western Views of Islam, 91-92.

45 For direct engagement with Postcolonial theory, see, e.g., Cohen, Postcolonial Middle Ages; Altschul, Postcolonialism and the Study of the Middle Ages; Gaunt, Can the Middle Ages be Postcolonial. It should be noted that much of the reception of relevant approaches in Medieval Studies took place indirectly, with reference to broader concepts of cultural history, transcultural history and connected/entangled history. On these concepts, see, e.g., the overviews in Hovden et. al. (eds.), Meanings of Community; Drews and Scholl, Transkulturelle Verflechtungsprozesse; Tolan and El Anabi (eds.), Identités en mutation; Krech and Steinicke, Dynamics in the History of Religion; Borgolte und Schneidmüller (eds.), Hybride Kulturen im mittelalterlichen Europa.

46 See the contributions in Azoulay and Boucheron (eds.), Le mot qui tue; Suerbaum et. al., Polemics; as well as Butler, Excitable Speech. 
This shift added a third and youngest layer of connotations to the concept of "polemic", now linking it to cultural hierarchies: the term no longer emphasized a body of texts and the positions articulated therein, or a form of argumentation which is somehow illegitimate, but rather a form of discourse aiming to disparage or devalue an opponent. Importantly, cultural devaluation and disparagement were now understood to take several forms, either using scholarly, purportedly objective argument or rhetorical aggression, invective and degradation. This usage thus cuts across older definitions of the polemical - in fact, the very boundary between legitimate and illegitimate, scholarly and non-scholarly forms of argumentation is shown to be dependent upon cultural hierarchies and the power relations undergirding them. As Edward Said's pioneering Orientalism classically set out in 1978, perceptions of cultural identity cannot be neatly classified into objective and rational scholarly discourses on one side and tendentious polemic on the other. Ideas of identity and alterity, which accumulate over long periods of time, instead typically permeate both scholarly and popular discourses, and may be deeply ingrained into the foundations of a society, including its academic institutions and disciplines. As Said pointed out in critical engagement with the optimistic modernization narratives of the 1960 s and 1970s, the application of scholarly thought to cultural prejudices (for example to historical religious polemics) may thus not only lead to their deconstruction, but also to a "scientification " and strengthening of these prejudices. Speaking about the assumed boundary between a more or less rational perception of religious others, Said specifically engaged with Southern's presentation of a growing rationalization of western views of Islam: as he pointed out, Southern did not observe "some body of positive Western knowledge which increases in size and accuracy [...] « but »Western ignorance which becomes more refined and complex [...]. For fictions have their own logic and their own dialectic of growth or decline. $\aleph^{47}$ Said's study thus cautions against a separation of more or less rational and irrational perceptions of cultural identities. A polemical dimension, in the sense of a devaluation of the religious opponent, may very well be present in elaborate, rational scholarly reasoning presenting itself as pointedly objective.

Though this theoretical perspective informs most areas of the study of religious polemics today, its focus on the cultural construction of identity and alterity has tended to direct attention away from the term "polemic « itself. Typically, the emphasis was on other analytical terms, most importantly on identities and techniques of "othering «. ${ }^{8}$ Other research has focused on persecution, studying physical violence and its legal underpinnings, ${ }^{49}$ or on symbolic or visual degradations..$^{50}$ Art historical approaches have developed fascinating perspectives on images depicting otherness and monstrosity. ${ }^{51}$ In other research areas, the focus has been on rhetorical and literary techniques of disparagement. The term "polemic " was often used in these approaches but not typically clearly defined. But ultimately, this more recent research seems to presuppose a fairly narrow understanding of polemics, equating it with forms of cultural disparagement.

\footnotetext{
47 Said, Orientalism, 62.

48 See below at note 119 .

49 See especially Iogna-Prat, Order and Exclusion; Moore, Formation of a Persecuting Society; Nirenberg, Communities of Violence; Holzem, Krieg und Christentum; recently, see also Koch, Patterns Legitimizing Political Violence.

50 See, e.g., Groebner, Defaced; Cuffel, Gendering Disgust; Abulafia, Religious Violence between Christians and Jews; and several contributions in Azoulay and Boucheron, Le mot qui tue.

51 See, e.g., Strickland, Saracens, Demons and Jews; Trivellone, Hérétique imaginé; Epstein, Dreams of Subversion.
} 


\section{Constituents and dimensions of the polemical: a preliminary checklist}

As set out above, the tensions within these research fields and the need to accommodate different, only partially overlapping research interests as well as highly diverse forms of religious polemics appear to make it more meaningful to assemble a typology of religious polemics rather than attempting a stringent definition. A necessarily modest starting point for further interdisciplinary work may be formulated in a composite definition or sconstituent checklist،, enumerating features or dimensions ascribed to medieval religious polemics.

Building on the definitions suggested in extant research, and particularly in some recent works which have sought to engage with the phenomenon and offered their own definitions, ${ }^{52}$ the present, preliminary checklist distinguishes eight different features which may appear in medieval polemical discourses (understood to include performance, text and images, though the focus is, admittedly, on texts). As I will discuss in the concluding section, discourses which only "verged on the polemical « might display one or two of these features, while discourses with the central intent to engage with a religious opponent often displayed several of them. In the following, the condensed list will be followed by a longer explanatory discussion engaging with relevant research. The list distinguishes two broad sets of elements.

The first four interrelated and partially overlapping characteristics concern the concrete realizations and social functions of polemical discourses, especially those polemics openly seeking to disparage an opponent:

(1.) Disparaging categorization: on the level of concrete utterances, polemical discourses made use of pre-existing cultural categories and hierarchies to devalue opponents.

(2.) Rhetorical aggression: polemical discourses often employed aggressive speech, using conventionalized rhetorical techniques and repertoires to attack an opponent's position while defending and extolling the speaker's own.

(3.) Public character and double audience: polemical engagements typically had a twofold audience and thus opened debate to a public (however circumscribed). They could be addressed primarily to a religious opponent or outgroup, or to an audience considered the speaker's ingroup, which was to be mobilized against the opponent. Often, polemical discourses addressed both of these audiences.

(4.) Construction of self and other: seen from a mid- and long-term perspective, polemics contributed to the construction and defence of complex cultural identities, usually by adapting pre-existing traditions to contrast the religious self with an other.

The second group of four characteristics concerns the methodologies and conflict strategies of polemical engagements, especially those engaging in scholarly argumentation.

(5.) Debatable legitimacy: polemical engagements could transgress the limits of legitimate argumentation or procedure in a given historical circumstance, or trigger arguments over such limits.

(6.) Pre-determined stances: some polemical engagements were conducted with a predetermined attitude and lacked open-endedness, as the polemical speakers felt that truth was already in their possession.

52 See n. 28 above. 
(7.) Scholarly methodologies: polemical engagements could draw on established practices of debate or scholarly methods to elaborate their religious standpoints, or produce specific agreements and compromises regarding such methodologies.

(8.) Epistemological asymmetries: polemical engagements might also be conducted within asymmetrical epistemological or methodological frameworks or produce such asymmetries, leading to a devaluation of the opponent's assessment of truth and preferred methodology.

\section{(1.) Disparaging categorization}

On the level of concrete utterances, polemical discourses make use of pre-existing cultural categories and hierarchies to disparage or devalue opponents. Though the term "polemical« today mainly evokes associations of aggressive speech, there can be no degradation or devaluation of opponents without underlying categories which established religious and cultural difference and assigned cultural hierarchy. ${ }^{53}$ Disparaging categories and hierarchies might then form the basis for disparaging rhetoric, and could, moreover, develop considerable impact if they became the foundation for legal or other normative categorizations. ${ }^{54}$ Conversely, a classification sorting an opponent into a pre-existing, negatively connotated category works quite well even today without aggressive verbal embellishment. In certain contexts, it can be derogatory to simply say "she is a woman!«. To cite a popular twentiethcentury phrase, a male opponent can be disparaged by claiming that he throws, runs or cries »like a girl«. This latter example, a polemical comparison, and thus a specific form of disparaging categorization, ${ }^{55}$ illustrates the force of categorization: to class a male opponent in a way which likens him to a woman or child is to question the opponent's value, marking him as deficient as a man or adult. A particularly popular, almost universal variant of this form of devaluation is the comparison (or identification) of humans with animals, especially animals considered impure, such as pigs or dogs, which denied the very humanity of the opponents and made open or implicit arguments for the necessity of guiding, controlling or even exterminating them..$^{56}$ In passing, it may be observed that polemics could emphasize the negative meaning of ambiguous or polyvalent categories. A male scholar might, for example, ascribe positive female roles of mothering to himself, while still ascribing negative female traits to a male opponent to disparage him. ${ }^{57}$

53 On this fundamental issue, see Azoulay and Boucheron, Violences intellectuelles, 44-48.

54 This point is made in depth by Moore, Formation of a Persecuting Society; Iogna-Prat, Order and Exclusion, and others.

55 On the use of comparisons to establish cultural hierarchies, see, e.g., Cavarzere, Comparative Method; Epple, Doing Comparisons, and in the future Brauner and Steckel, Wie die Heiden - Wie die Papisten.

56 On animal metaphors in medieval inter-religious polemics, see Cuffel, Gendering Disgust, 198-239. Particular themes include the Judensau, cf. Shachar, Judensau; Wiedl, Laughing at the Beast. On dogs, see, e.g., Resnick, Good Dog/Bad Dog. On the polemical use of animal metaphors in literary forms such as the beast epic, cf. the contributions in Scheuer and Vedder, Tier im Text; Lembke, Biblical Creatures.

57 See Cuffel, Ibn Sahula's Meshal Ha-Qadmoni. 
Many categories employed in disparaging categorizations are common in several religious traditions and in intra- as well as inter-religious polemics. This appears partly due to the fact that they revolve around basic anthropological constants: much disparagement is based on gender and age, on humanity versus animal nature, on the natural as opposed to the unnatural, the healthy as opposed to the sick, the pure as opposed to the impure. But in the wake of influential studies like Mary Douglas's "Purity and danger,$^{58}$ research has mostly emphasized distinct cultural forms. As Douglas argued, the cultural construction of purity and pollution appears strongly linked to concepts of social order in most societies. Yet cultural differences might still lead to divergent reactions and perceptions in encounters between culturally different protagonists. Within the Islamicate world, for example, we encounter polemics against blue- and green-eyed people, which build on the understanding of blue eyes, which were considered unremarkable in other regions, as unnatural or sick. ${ }^{59}$ Recently, however, several studies have highlighted that polemical engagement between religious traditions might also cause the convergence of cultural assumptions, as, for example, in the development of shared perceptions of corporeal and sexual impurity among high medieval Jewish and Christian interlocutors, ${ }^{60}$ or in related rules governing the proper use of food. ${ }^{61}$

A comparative perspective on disparaging categorizations also highlights that confrontations often revolved around the differentiation of religion from other societal spheres or fields: controversies between different religious groups often emphasized their different understanding of the ideal relationship of religious norms to other spheres, such as scholarly, economic or political practices. ${ }^{62}$ Both in Christian-Jewish encounters and in many dissenting movements within medieval Christianity, for example, the religious regulation of business practices and attitudes towards money and riches became highly contested. The debates and eventual polemics generated by these conflicts caused several categories negotiating the boundaries of religious and economic life (such as greed, avarice, usury, or deceit) to take on new symbolic charges, which made them more apt for disparagement and connected them to specific groups, such as the usurious Jews and the greedy Christian prelates. An even more strongly instrumentalized relationship is that of religion and scholarship: besides many references to categories regulating morality, the strong emphasis on intellectual contest typical for Judaism, Christianity or Islam led to an early insistence on the categories of (intellectual) blindness and insanity, i.e. deficiencies in cognition and human rationality, as well as accusations of a lack of intellectual or scholarly competence. ${ }^{63}$

58 Douglas, Purity and Danger; cf. also Duschinksy et. al., Purity and Danger Now.

59 Richardson, Blue and Green Eyes. See also, generally, Kim, Reframing Race and Christian/Jewish Relations.

60 See Cuffel, Gendering Disgust; Marcus, Christian-Jewish Symbiosis.

61 Freidenreich, Foreigners and their Food.

62 On the historical differentiation of religion, see Bourdieu, Gènese et structure du champ réligieux; I am currently preparing an article on the subject entitled The medieval religious field. Framing processes of religious transformation in late medieval and early modern Europe.

63 For ancient foundations, cf. Opelt, Lateinische Schimpfwörter, 228-237, for the Christian tradition, cf. Opelt, Polemik in der christlichen lateinischen Literatur. On types of disparagement, see also Destemberg, Espace public de la polémique, at nn. 26-35. 
Another relevant class is constituted by different categories negotiating the intersection of religion and the realm of (religious) law. ${ }^{64}$ There has already been substantial analysis of the way legal discourses constituted religious differences and interfaced with the realm of the political in the imposition of sanctions or outright persecution. Important studies on high medieval Latin Christianity, such as Robert I. Moore's hypothesis of the "formation of a persecuting society" during the High Middle Ages and Dominique Iogna-Prat's study of the religious "order and exclusion" envisioned by the Cluniac abbot Peter the Venerable († 1156), have emphasized the marked consequences which legal and theological systematization had on the perception and eventual persecution of religious difference. ${ }^{65}$ But the argument they make for Christianity might be applied more widely: the specific class of categories straddling the spheres of law and religion - i.e. categories defining the boundary of the religious community, such as heresy, unbelief, apostasy or blasphemy - constitutes a particular field of interest for comparative and connected studies, such as Christine Caldwell Ames' recent monograph on heresies in medieval Christianity, Judaism and Islam. ${ }^{66}$ Recent research has already highlighted further types of polemical categorizations which draw on religious, legal and political connotations. A particular form of categorization highlighted in comparative research consists in the identification of religious opponents with apocalyptic figures and groups, ${ }^{67}$ such as the Antichrist, Gog and Magog, or the hypocritical harbingers of the Antichrist. ${ }^{68}$ Comparative approaches might also profit from the study of a complex category like hypocrisy, which negotiated the boundary of the religious field by implying that an opponent was not a "real « Christian, Muslim or Jew, but only possessed a semblance of genuine religiosity. ${ }^{69}$

Of course, any comparative or connected work will have to invest considerable energy in the reconstruction of the genealogies of some particularly charged categories. An intriguing type of categorization, for example, consists in coded or metaphorical names, i.e. negatively charged religious or ethnic labels, such as "Pharisees «, often drawn from normative or sacred texts and applied figuratively to mask the object of a polemical attack. Especially in situations where the power balance did not allow polemical authors to engage a powerful opponent directly, such covert polemics - for example addressed to unnamed "hypocrites" - could open up the possibility of presenting fairly complex arguments..$^{70}$ Whereas some polemical labels became commonplace and took on the quality of easily-understood insults, as seems to have been the case with the "Goliardi« of Latin satire,${ }^{71}$ other pseudonymously attacked

64 See, e.g., the volume series Tolan et. al. (eds.), Religion, Minorities and the State, e.g. Tolan and Boisselier, Religious Cohabitation; Tolan et. al., Jews in Early Christian Law; Fierro and Tolan, Legal Status of Dimmi-s.

65 Moore, Formation of a Persecuting Society; Iogna-Prat, Order and Exclusion.

66 Ames, Medieval Heresies.

67 See generally Kienzle, Preaching as Touchstone; Schmieder, Prophetische Propaganda in der Politik.

68 For examples, see, e.g., Brandes et. al., Peoples of the Apocalypse.

69 On hypocrisy in different cultures see, e.g., Adang, Hypocrites and Hypocrisy; Elmer, Pillars, Hypocrites and False Brothers; Steckel, Falsche Heilige; Emmerson and Herzmann, Apocalyptic Age of Hypocrisy; Berger, Introduction, 96.

70 See, e.g., Emmerson and Herzman, Apocalyptic Age of Hypocrisy; Steckel, Ein brennendes Feuer in meiner Brust, with examples from Latin Christianity.

71 See, e.g., Mann, Satiric Subject and Satiric Object. 
groups could only be identified by audiences possessing specific background knowledge. In some cases, the decoding of addressees, or the reconstruction of the message such polemics expressed »between the lines", could demand considerable sophistication on the part of the audience. $^{72}$

\section{(2.) Rhetorical aggression}

On the basis of different cultural categories and hierarchies, polemical discourses often made use of aggressive speech, using specific rhetorical repertoires and techniques to attack an opponent's position while defending and extolling the speaker's own. In the introduction to their recent volume, Southcombe, Suerbaum and Thompson thus begin their definition of polemic by describing "strong and hostile language, suggestive of violence and warfare ${ }^{73}$ Alain de Libera, Bénédicte Sère and others have also emphasized the "agonality« of Christian scholasticism, which imbued medieval and early modern techniques of debate and led to the cultivation of a vocabulary of intellectual warfare and battle. ${ }^{74}$ Jürgen Stenzel characterizes polemic by highlighting its confrontational $»$ rhetorical Manichaeism ${ }^{75}$ which polarized a debate and painted the self and the other in stark black and white. However, more precise descriptions of the aggressiveness or violence of polemics are surprisingly hard to find - probably because there are many possible levels and approaches as well as different languages and rhetorical traditions to explore. Examples for some of them in the following are drawn from the rhetorics of Christian medieval Latinity.

Generally, one may note that the rhetoric used in engaging the person of an opponent often draws on the semantic field and registers of warfare in the Latin Middle Ages - but this is by no means the only prominent field. Quite often, vocabulary referring to intellectual engagement as warfare or battle actually pursued an irenical strategy, stressing the polemicist's aversion to violence and ascribing illegitimate violence to the opponent. ${ }^{76}$ As mentioned in the discussion of categorization, the issues of moral deficiency, but also of intellectual deficiency or physical deformity played a role. ${ }^{77} \mathrm{~A}$ cross-disciplinary overview of typical themes of invective or offensive speech appears to be lacking, even within the realm of Latin. ${ }^{78}$

72 On the reading of subtexts and identification of esoteric meaning, see classically Strauss, Persecution and the Art of Writing; for covert biblical polemics see Amit, Hidden Polemics in Biblical Narrative.

73 Southcombe et. al., Introduction, 6.

74 See Sère, Thomas d'Aquin, with reference to De Libera, Penser au Moyen Age, 155; Destemberg, Espace public; Füssel, Gelehrtenrepublik im Kriegszustand.

75 Stenzel, Rhetorischer Manichäismus.

76 Cf. Destemberg, Espace public, at n. 40; see also the examples cited ibid., at note 7-8.

77 See the various approaches in Cuffel, Gendering Disgust; Desmons and Paveau, Outrages, insultes, blasphèmes et injures; Opelt, Lateinische Schimpfwörter; Opelt, Polemik in der christlichen lateinischen Literatur.

78 But see the catalogues developed by Opelt, Lateinische Schimpfwörter; eadem, Polemik in der christlichen lateinischen Literatur; Destemberg, Espace public, at n. 25-35; Dahan, Intellectuels chrétiens, 361-421; Kienzle, Preaching as Touchstone. 
In general, research on the rhetorical norms governing polemical engagements in Latin appears surprisingly fragmented. The Latin Middle Ages inherited the concepts of vituperatio and invectiva ${ }^{79}$ from Antiquity, but the ancient handbooks of rhetoric yielded few concrete patterns, and literary examples therefore provided the most important impulses for shaping antagonistic rhetoric. Latin invective, for example, took up impulses from early texts such as Pseudo-Sallust's Invectivae or the church father Jerome's († 415) Contra Rufinum. ${ }^{80}$ Christian rhetoric also elaborated its own modes of public religious speech, such as exhortation, increpatio or admonitio, which blended exhortatory and didactic elements with invective. ${ }^{81}$ Practical advice on different forms of disparagement such as invectiva and satira ${ }^{82}$ was eventually included in poetical handbooks, and influenced the rhetoric of letters and sermons, two genres which lent themselves to polemics very well. ${ }^{83}$ Later on, humanist literary practices rediscovered the ancient form of invective and reinvigorated it. ${ }^{84}$

But of course, practically every device and flourish of rhetorical elocutio could be instrumentalized to lend expressive force to polemical speech. A few typical persuasive operations have been highlighted: polemical rhetoric tended to polarize, creating black and white options. Polemicists typically also accentuated any uncontroversial points to strengthen their position, while omitting or minimizing the corresponding unfavourable points. Other favourite persuasive techniques include generalization, for example in stereotypes, and insinuation, which anticipated or hypothesized bad intentions or characteristics. ${ }^{85}$ As such cases show, polemical rhetoric may depend largely on the audience for a full reconstruction of its potential meaning. In particular, some forms of "covert « polemics, for example satirical texts with allegorical actors, actually managed to put much of the work of meaning-making onto the shoulders of the audience. Where insider knowledge was necessary to decode covert polemics, this also established a bond (however weak) between the polemicist and the collaborating audience, who shared in the identification of the opponent and might, in cases of a genuinely "esoteric" subtext of a polemic, feel glee or intellectual superiority at being "in the know". In some cases, the decoding might even force the recipient to draw conclusions which only emerged once the polemical argument was »translated « and applied to its actual target. Inviting readers to such reconstructions, which forced them to apply techniques usually cultivated in the allegorical interpretation of literature, of sacred texts or of legal norms, might thus also be considered as a polemical strategy, so far mainly investigated for poetical texts and especially animal allegories. ${ }^{86}$

79 Cf. Neumann, Invektive; Helmrath, Streitkultur; Garcia and Beaumatin, Iinvective. On invective in Antiquity, see also Opelt, Lateinische Schimpfwörter.

80 See the discussion in Neumann, Invektive; Helmrath, Streitkultur; Opelt, Lateinische Schimpfwörter; Opelt, Polemik in der christlichen lateinischen Literatur.

81 On admonitio, see De Jong, Admonitio and Criticism of the Ruler; Suchan, Mahnen und Regieren; Weiler, Clerical admonitio. The ongoing dissertation of Andra Alexiu (Münster/Bucarest), Confront and Admonish: Hildegard of Bingen and Female Monastic Agency, will contain a study of twelfth-century admonitio and its use in intra-Christian polemic, cf. her shorter contribution in this volume.

82 On the medieval notions and polemical use of satire, see Kindermann, Satyra; Kendrick, Medieval Satire; and, e.g., McGuire, Anti-Clerical Invective; Levine, Why Praise Jews.

83 Cf. Helmrath, Streitkultur, 262.

84 See, e.g., Helmrath, Streitkultur; Baumann et. al., Polemik im Dialog des Renaissance-Humanismus; Anheim, Humanisme est-il un polémisme.

85 Cf. Stenzel, Rhetorischer Manichäismus, 7-8.

86 See the literature above, n. 55., and see the remarks in Doležalová, Passion and Passion. 
A particularly intriguing aspect of medieval (and modern) rhetoric is often acknowledged, but lacks systematic or comparative treatment for polemical discourses so far: polemical engagements often attempted to evoke physical and emotional reactions in their audience. Following and reflecting upon the precepts of the ancients, such as Aristotle's Rhetoric, many medieval Latin polemics developed highly functional techniques of appealing to and instrumentalizing emotions. But there are, as yet, only a few studies linking the theme of polemics to the thriving research area of the history of emotions, ${ }^{87}$ which is currently offering many new impulses for research interested in the emotional standards and emotional regimes visible in particular historical constellations.

Given the polarization and instrumentalization of emotions in current political cultures and social media, this topic appears highly relevant, and further research could profit from the work already done in a number of different sub-fields. Some research, like Alexandra Cuffel's important study of the use of gendered polemics of disgust in medieval inter-religious encounter, has looked at the use of the body in religious polemics. ${ }^{88}$ Drawing on the assumption that concepts of impurity and inappropriateness shape affective regimes, Cuffel analyses polemical references to disease or deformed bodies. As she reminds us, such techniques might generate an immediate, visceral reaction of disgust, which audiences could not fully control or subject to rational evaluation..$^{89}$ Another approach has focused on techniques of shaming or of challenging an opponent's honour, which often formed part of polemical encounters. ${ }^{90}$ Several studies have also dealt with the use of ridicule as a means of disparaging an opponent, ${ }^{91}$ in particular with satire, which has drawn interest in literary as well as historical studies. ${ }^{92} \mathrm{~A}$ further promising field seems to lie in polemical strategies which consciously activated emotionally charged subjects, such as the desecration of holy places or the killing of women and children, ${ }^{93}$ or try to overwhelm listeners with feelings of rightful indignation, anger, or fear to lock them into pre-defined scripts for specific emotional reactions meant to trigger actions. Scholars working on pre-modern periods might perhaps even look towards the analysis of current political culture to find new frameworks for such forms of polemic, and experiment with theories of "affective polarization ${ }^{94}$ or more generally with the theories of »framing" of multi-layered political messages developed in media studies and political science. ${ }^{95}$

87 See, e.g., Till, Text, Kommunikation und Affekt; Sauer, `Bringing Emotions Back in‘; Clement, Introduction. On the history of emotions, see the recent overviews and discussions in Miller and Wheatley, Emotions, Communities and Difference; Plamper, History of Emotions; Rosenwein, Generations of Feeling; Nagy and Bouquet, Sujet des émotions; Bouquet and Nagy, Sensible Moyen Âge.

88 Cuffel, Gendering Disgust. See also eadem, Matter of Others; for Antiquity, see, e.g., Taylor, Body in Biblical, Christian and Jewish Texts, for the Reformation period, e.g., Scribner, Popular Culture and Popular Movements, 54-69, 295-99.

89 Cuffel, Gendering Disgust, 5-9.

90 See, e.g., the contributions in Groebner, Defaced; Freudenberg, Irarum nutrix; Knappe, Flyting und die Rhetorik des verbalen Konflikts; Smail, Consumption, of Justice, ch. 2; White, Feelings in the Feud.

91 See, e.g., Scharff, Lachen über Ketzer; Zellentin, Rabbinic Parodies; Röcke and Velten, Lachgemeinschaften; Classen, Laughter in the Middle Ages.

92 See the literature in n. 81 above and, e.g., Cailly, Les fabliaux; Mann, Chaucer and Medieval Estates Satire; Burrows, Stereotype of the Priest; Schüppert, Kirchenkritik in der lateinischen Lyrik.

93 See, e.g., the observations in Signori, Frauen, Kinder, Greise und Tyrannen; Shalev-Eyni, Martyrdom and Sexuality.

94 See, e.g., Lau et. al., Effect of Media Environment Diversity; Marcus et. al., Affective Intelligence; Iyengar and Westwood, Fear and Loathing across Party Lines.

95 See, e.g., Lakoff and Wehling, Your Brain's Politics; Matthes, Framing. 


\section{(3.) Public character and double audience of polemics}

A third characteristic of polemical discourses is that they typically spoke to a twofold audience and thus either utilized or created a public sphere of debate. Polemics could be addressed primarily to a religious opponent, or "outgroup «, or to an audience considered the speaker's "ingroup", which was to be mobilized against the opponent or confirmed in its adherence to the speaker's position..$^{96}$ There is a strong consensus in research that this latter, consolidating or mobilizing function of polemics contributed greatly to the construction of religious identities and frequently affected or even completely overlaid the intention of attacking an outgroup. This issue will be revisited in a moment. As a basis for further discussion, it should first be noted that the distinction between polemics addressed to an internal or towards an external audience is one of ideal types and can be somewhat misleading. Extant work on polemical engagement in fact shows a broad variety of possible audiences and of the possible institutional frameworks and public spaces for polemics, and it is these historical contexts which lie at the heart of any form of contextualization. Any future comparative work, and any attempt to connect different historical strands of religious polemics, will, in fact, have to engage with the constantly changing reception contexts and shifting intended audiences of polemical arguments, which may at first glance appear traditional and repetitive, but often show minuscule changes which need to be tied to specific contexts.

Research on medieval Jewish anti-Christian polemic provides examples which quickly deconstruct the notion that distinctions between different audiences of polemic might be easy to draw. In a useful functional classification of such texts, Jeffrey Cohen has highlighted four functional types of anti-Christian polemic from the medieval centuries, ${ }^{97}$ which can, for the purposes of this overview, be grouped into three different types primarily addressing Jewish audiences, and one type primarily addressing Christian interlocutors and persecutors. As Cohen outlines, the relatively low intellectual engagement between Christians and Jews during the early medieval centuries led to an adaptation of the polemics developed during late Antiquity. The intellectual exchange which had accompanied the "parting of the ways « ${ }^{98}$ was largely supplanted by inward-looking texts, "polemic for the community of the faithful «, ${ }^{99}$ for example the derogatory folktales of the Toledot Yeshu, or liturgical poetry evoking anti-Christian sentiments, which mainly served to confirm Jewish identity. ${ }^{100}$ But this type of polemic was complemented when intellectual engagement resumed during the twelfth century: a new type of polemical texts still addressed Jews as their proximate audience, but mainly functioned as "guidebooks for direct confrontation ", offering arguments and authorities which might be used for disputations with an ultimate audience of Christian opponents. ${ }^{101}$ From the thirteenth century onwards, a third type of polemics then reflected a shift in circumstances towards a "defence of the faith [...] on trial«, which was geared much more towards the Christian opponents of Jewish authors because the institutional framework of

96 Thus, e.g., Southcombe et. al., Introduction, 6; Stauffer, Polemik, 1403; Hettema and Van der Kooj, Introduction, xiv-xv.

97 Cohen, Towards a Functional Classification.

98 Cf. Boyarin, Border Lines; Becker and Reed, Ways That Never Parted.

99 Cf. Cohen, Towards a Functional Classification, 94-99, at 94.

100 See, recently, Cuffel, Between Epic Entertainment and Polemical Exegesis.

101 Cohen, Towards a Functional Classification, 99-104.

medieval worlds $\bullet$ No. $7 \cdot 2018 \cdot 2-60$ 
encounter had shifted. Jewish communities were now under mounting pressure from Christian persecution, and Christian polemicists were beginning to charge Jewish scholars with alleged deviance from the tenets of genuine Judaism, and thus a form of heresy. Though new polemical texts of this period were still often based on situations of disputation, and still gathered arguments which might be used by Jews in further engagements, such encounters were increasingly shaped by coercion and the threat of physical violence. This highly asymmetrical power balance skewed the trajectory of argumentation on the side of Jewish polemicists, causing a highly defensive stance which mainly reflected the agenda of their Christian persecutors. The tensions of the situation at times even forced Jewish polemicists into a more accommodating and tolerant stance towards Christianity, intended, at least in part, to placate a hostile audience of Christians. ${ }^{102}$ Finally, however, a fourth type of polemical text went the opposite way and attacked Christianity more openly, while also addressing itself more firmly to Jewish audiences again. As the late medieval expulsions of the Jews from several European realms and eventual mass conversions of remaining Jews in Iberia heightened the pressure on Jewish communities, a diverging strategy of anti-Christian polemics now engaged in open "condemnations of the aggressor «. Such polemics aimed to discourage the remaining Jews from conversion, showing that Christianity was "not an option «. ${ }^{103}$ This produced much more disparaging and hostile texts, though Jewish authors often engaged with Christianity on an elevated intellectual level as well. Intriguingly, they now transferred and mirrored many accusations which Christian authors had earlier levelled against Judaism, such as deviance from previous, authentic norms.

As this highly compressed overview shows, polemics might not only address themselves to different audiences, but also appeal to these in different ways, shaped by the different legal, intellectual and political constraints on the situation of encounter and by the different political and cultural circumstances of the groups involved. In charting the transformation of particular types of polemics, both these changing contexts and possible shifts in audience - towards the external audience of the outgroup, or towards the ingroup of the polemicist's own community - need to be scrutinized.

Especially in a comparative perspective, however, such further scrutiny will probably also force us to engage more closely with different cultural constellations of "the public«. The public cultures emerging across different medieval societies over the centuries form a highly active if, again, rather fragmented research field, and any attempt to locate polemics within particular public spaces will have to engage with it. ${ }^{104}$ Three distinct issues may be noted for future research.

Firstly and generally, much of the attention which has been devoted to the analysis of medieval public culture (at least for Latin Christianity) has ultimately had a focus on the political public, both in drawing on modern models of the "public sphere of politics such as Jürgen Habermas's celebrated model, and in focusing on highly political debates such as the eleventh- and twelfth-century Investiture Contest with its re-evaluation of the relationship

102 Cohen, Towards a Functional Classification, 104-109.

103 Cohen, Towards a Functional Classification, 109-112.

104 For recent overviews and analyses, see Connell, Popular Opinion in the Middle Ages; Jaspert, Politische Öffentlichkeit im Spätmittelalter; Langer and Fierro, Public Violence. For the publicness of polemics, see the remarks and literature in Destemberg, Espace public. 
of religion and politics. ${ }^{105}$ By contrast, the study of religious polemics throws up the question of how far the structures of public debate generated by religious conflicts might differ from the debating of politics. ${ }^{106}$ To follow up on this approach, we may have to look to other models, for example approaches to the public of the European Reformation ${ }^{107}$ - or, again, engage directly with scholars discussing current political culture.

This leads to a second, related observation: modern models often postulate a "public sphere« or "public space« which, given the singular, appears as a unified structure. Against this, some medievalists have insisted that given the communication practices, media, and group structures of medieval societies, we are mostly faced with overlapping publics or textual communities, many of which remained "occasional « publics, dependent on intermittent meetings of otherwise dispersed elites. ${ }^{108}$ On the other hand, it has been argued that some of the most intense conflicts produced a coherent public sphere, which managed to connect elite and popular discourses to enable genuinely public debate. ${ }^{109}$ In analysing polemical debates and their different venues and institutional frameworks, both argumentations have a bearing: clearly, different sorts of polemical engagements were anchored to different venues of public debate. The constellations which produced specific religious polemics, and, all too often, also violence against religious others, may often have been defined by the circumstances of local "communities of violence ${ }^{110}{ }^{10}$ But at the same time, other forms of religious polemics bridged different venues, contributing to the constitution of public debates in the sense of multi-level discourses debated across interrelated communication networks. ${ }^{111}$ As several scholars have pointed out, urban spaces were particularly apt to act as communication hubs for such religious debates. ${ }^{112}$

Viewed from a mid- and long-term perspective, the public of polemics was continually being constituted and reconstituted, often in a circular pattern which shows episodic reworkings of polemical discourses: polemical texts were produced once discussion in scholarly, legal or political venues had failed to establish a solution for religious conflicts. Either both sides or just the disempowered party of a conflict might take refuge in polemics, attempting

105 Cf. Melve, Inventing the Public Sphere, who advocates an adaptation of the model elaborated in Habermas, Strukturwandel der Öffentlichkeit.

106 That the political sphere developed its own public is argued in Schlögl, Politik beobachten, but no consequences for religion are drawn.

107 Possible models include the observations in Scribner, For the Sake of the Simple Folk; Wohlfeil, Reformatorische Öffentlichkeit; but also recent approaches to late medieval media cultures such as Corbellini, Cultures of Religious Reading.

108 The term »occasional public« was coined by Thum, Öffentlichkeit und Kommunikation. On the fragmented and overlapping nature of medieval networks of public communication, see Jaspert, Politische Öffentlichkeit, 435; Steckel, Professoren in Weltuntergangsstimmung.

109 Melve, Invention of the Public Sphere.

110 See, e.g., Limor, Polemical Varieties, and Nirenberg, Communities of Violence.

111 On the dynamics of large-scale political debates, see, e.g., Sère, Débats d'opinion. On »shared spaces« generated by scholarly exchanges, including polemics, see, e.g., Brentjes, Medieval Portolan Charts; Stroumsa, Thinkers of "This Peninsula«.

112 See, e.g., Symes, A Common Stage; Jaspert, Politische Öffentlichkeit; Steckel, Professoren in Weltuntergangsstimmung. 
to mobilize further support, and spreading ideas and arguments in texts or dossiers prepared specifically for this purpose, such as dialogues or disputationes, leading to dissemination across existing social networks. ${ }^{113}$ In some cases, new conflict episodes would then be triggered by new rounds of polemics, which constituted a new "occasional public « by openly breaking the established consensus in written form or face-to-face encounter, triggering a next round of controversy in which the opponents were called upon to defend their position. ${ }^{114}$ In contrast to texts produced to mobilize the polemicist's own community, more offensive polemics might either address an opponent directly or appeal to political or legal instances invested with the authority to reopen the debate, such as princes or high-ranking religious figures. The tension between the postulate of a coherent, singular public debate and the multiplicity of local communication networks thus appears ultimately solvable: local communities, supra-local structures of conflict resolution and overarching communication networks linking the parties would all play their part, with specific constellations depending on the degree of mobilization enabled by polemical efforts and local constraints.

Yet the nature of religious polemics also points to a different sort of fragmentation, which the Habermas model of a unified "public sphere" tends to obscure, prompting a third consideration: as the case of Christians and Jews within Latin Europe again underlines, polemics might result in the establishment of separated publics, some of which constituted "subaltern counterpublics «. ${ }^{115}$ That such competing publics confronted each other has been illustrated from various perspectives in the history of Jewish-Christian relations. On the Christian side, polemical discourses contributed significantly to public demonstrations of cultural hegemony within the public space - for example in the use of public images which disparaged Judaism, such as depictions of the "Judensau" on public buildings, ${ }^{116}$ or the desecration of Jewish tombstones which were affixed to Christian houses. Answering Jewish polemics in contrast marked out the spaces and occasions constituting the "counterpublic«, such as the Jewish liturgical poetry disparaging Christianity. ${ }^{117}$ As research on intra-Christian debate culture has recently begun to break away from the Habermas model, this might be another important area for comparative approaches. ${ }^{118}$

113 On the functions of such texts, see, e.g., the observations in Limor, Polemical Varieties; Ragacs, Reconstructing Medieval Christian-Jewish Disputations; Hames, Reconstructing Thirteenth-Century Jewish-Christian Polemic.

114 Cf. Destemberg, Espace public, at n. 14.

115 On this concept, cf. Fraser, Rethinking the Public Sphere, 66-67.

116 See Wiedl, Laughing at the Beast; Scholl, Materielle Hinterlassenschaften als Zeugen.

117 See, e.g., Keil, Orte jüdischer Öffentlichkeit; Yuval, Pessach und Ostern, but cf. also the instances of business documents mentioned by Wiedl's contribution in this volume (at $\mathrm{n} .14$ )

118 See, e.g., Sère, Débats d'opinion; Steckel, Professoren in Weltuntergangsstimmung. 


\section{(4.) Construction of self and other}

Seen from a mid- and long-term perspective, many forms of polemic contributed to the construction and defence of complex cultural identities, usually by drawing on pre-existing traditions, social imaginaires and pluri-medial knowledge archives to contrast a self with an "other « ${ }^{119}$ This characteristic of polemics has important consequences, as it inscribes polemical engagements into pre-existing identity discourses, whose constituent arguments, images, symbols and spaces were appropriated, instrumentalized or polarized. ${ }^{120}$ In the circular pattern of defence and renewed offence characterizing polemical episodes, individual polemicists would draw on established identities anchored in the memories and documents of their communities, but also contribute to the adaptation and continuation of such knowledge archives.

On one side of this cycle, pre-existing religious identities, stored in the collective memory in the form of cultural categories, rhetorical repertoires, texts and images which might be used in polemical engagements, formed a cultural resource for the polemicist, and many polemical discourses were highly tradition-oriented. ${ }^{121}$ Partly, this is simply a result of typical argumentative techniques: in engaging with an opponent, it was an excellent strategy of disparagement to identify or liken the opponent to traditional enemies and religious others, for example to known groups of heretics. To call a thirteenth-century Cathar Good Man a "Manichaean" would not only call up the intellectual arguments which had already been made against the Manichaeans of Antiquity by authorities such as the church father Augustine, suggesting that the opponent was defending a position long dismissed as untenable; it might also activate the emotional and symbolic charges which connected to historical heresies in the collective memory of a thirteenth-century community. If an audience's knowledge about such stereotypical others contained gory details implanted by earlier propaganda, for example the assertion that heretics (or Jews) ritually sacrificed children, even brief references might evoke strong feelings. ${ }^{122}$ The persuasive force of an argument could thus partly be derived from the unspoken elements of an established stereotype, which the addressees would supply by way of memory and association. ${ }^{123}$

In some pragmatic settings, for example in legal courts dealing with many heterogeneous conflicts, other factors such as routinization could contribute to the stereotyping of religious opponents. Grundmann famously demonstrated how the identification of old and new heretics could proceed through practical transfers: ${ }^{124}$ a questionnaire influenced by legal decrees and developed in the interrogation of one heretic might shape the expectations of the interrogators, and from there influence the questions asked of other dissenters, resulting in an assimilation and homogenization of originally heterogeneous instances of dissent

119 On techniques of othering, see the observations of Said, Orientalism, which seem à propos in the study of polemics, but also the overview in Ashcroft, Postcolonial Studies, 154-159; Höfert, Alteritätsdiskurse.

120 See, e.g., Southcombe et. al., Introduction, 6; Przybilski, Beispiele antichristlicher Polemik, 253-255.

121 Van der Wall, Ways of Polemicizing.

122 On the background, see, e.g., the literature mentioned in Rose, Murder of William of Norwich.

123 For an overview of these functions of stereotypes, see, e.g., Schrage, Von Ketzern und Terroristen.

124 Grundmann, Ketzerverhöre des Spätmittelalters als quellenkritisches Problem.

medieval worlds $\bullet$ No. $7 \cdot 2018 \cdot 2-60$ 
into an apparently coherent »sect«. Moore's hypothesis of the "formation of a persecuting society« in Latin Christian Europe during the high Middle Ages makes a similar argument on a grander scale, linking the new scholarly sophistication of legal and theological categorization of religious deviance and impurity developed during the twelfth century to a result of systematized persecution, which led to an assimilation of heretics, Jews, and Muslims, but also lepers. ${ }^{125}$

The influence of tradition is, finally, most strongly felt in cases where polemical elements had time to become absorbed into identity discourses and established themselves firmly in genres usually addressed to a religious ingroup. The stereotypical »Jew of Christian polemical discourses is the best-researched relevant figure. From Late Antiquity onwards, medieval didactic and theoretical genres, such as biblical exegesis, transported images of Jews, heretics and pagans, so that Christian perceptions of Jews were largely determined by the "hermeneutical Jew « (Cohen) constructed by Christian authors. ${ }^{126}$ Such constructions not only distorted the perception of individual Jews, but took on a life of their own, and often served a number of social and political functions. ${ }^{127}$ Several studies have explored the extreme cases of such othering, for example religious polemics which instrumentalized physically absent opponents. Late medieval polemics against Jews in regions like England, Scandinavia, France or Italy, where the Jews had been expelled, created »virtual Jews « ${ }^{128}$, whose image could be drawn upon for various purposes of boundary- and identity making.

If we look towards the different ways in which particular traditions of religious othering were remembered and archived, and how such discourses transformed over time, there is a fairly dense research landscape, but also some gaps, which typically result from issues of diverging chronology, geography or different genres, languages and disciplinary boundaries within research. In the history of Jewish-Christian encounter, for example, there is a fairly clear (if not completely linear) narrative of ongoing deterioration of the mutual relationship. ${ }^{129}$ Research on Islam and Christianity appears to be in the process of revising older narratives. ${ }^{130}$ But the current view on polemical traditions within Latin Christianity is less coherent. The question of longer trajectories has been controversial, with the relative weight of long- and short-term studies coming under detailed scrutiny. The opposing positions have been defended with a focus on persecution: Moore's "Formation of a Persecuting Society" argues for a long-term view on the emergence of religious persecution, but actually considers the long twelfth century with its marked formation of cultural hierarchies as a decisive turning point in its history. Nirenberg's "Communities of Violence", by contrast, insists on

125 Moore, Formation of a Persecuting Society.

126 Cf. Cohen, Living Letters of the Law.

127 On the spread of anti-Judaism across particular societies, see, e.g., Bale, Jew in the Medieval Book; Rubin, Gentile Tales; Hohlstein, Soziale Ausgrenzung im Medium der Predigt; Niesner, Wer mit juden well disputiern. A more systematic argument is made by Nirenberg, Anti-Judaism.

128 See, e.g., Tomasch, Postcolonial Chaucer and the Virtual Jew; Johnson and Blurton, Virtual Jews; further accents in Hess and Adams, Fear and Loathing in the North; Pogossian, Jews in Armenian Apocalyptic Traditions.

129 See, e.g., Chazan, From Anti-Judaism to Anti-Semitism; Cohen, Living Letters of the Law; Abulafia, Jewish-Christian Relations.

130 See generally the literature above, n. 7, especially König, Arabic-Islamic Views. 
the dynamism and differences of local constellations, implying that individual local conflicts might have drawn on similar cultural patterns, but nevertheless remained largely shaped by specific circumstances. ${ }^{131}$ Other studies have fought similar battles over different strands of polemics. ${ }^{132}$ Several authors like Wendy Scase and, recently, Guy Geltner, for example contested Penn Szyittya's earlier hypothesis that there was a fairly homogeneous, century-spanning intellectual tradition of "antifraternalism «, i.e. religious polemic targeting mendicant friars. ${ }^{133}$ Seen from a bird's eye view, these debates mainly illustrate that historical work must draw on combinations of the long- and the short-term approach, and needs to balance both approaches to show how individual events and larger cultural structures affected each other.

Problems arise if this balance is lacking, and research therefore has to fall back on modern master narratives concerning the role of religion in society. In the study of intra-Christian polemics, the influence of such older master narratives and their competing and contradictory historical trajectories is indeed still keenly felt. The most important polemical category structuring the religious field of Latin Christianity, that of heresy, has a long research history even before Grundmann's seminal warnings about stereotyping, but we actually have few long-term studies. Hans-Werner Goetz's reconstruction of the perception of heresy and other religious groups (Paganism, Judaism, Islam and Orthodox Christianity) has recently shown the wealth of material regarding the earlier Middle Ages, which have a tendency to be overshadowed by the "hotspot " high medieval centuries. ${ }^{134}$ Lucy Sackville's study of the thirteenth-century image of heresy in Latin Christianity has also clarified some of the dynamics and consolidation processes that the category of "heresy" was subjected to. ${ }^{135}$ Yet especially for the later Middle Ages, the overall record remains patchy ${ }^{136}$ - even though it seems clear that heresiology is a master discourse on which many other polemical discourses drew. ${ }^{137}$ The perception of heresy not only became entangled in the Latin encounter with Islam and Judaism from the high Middle Ages onwards, but also furnished the elements for several other intra-Christian polemical traditions, among them polemics against reform-resistant clergy ${ }^{138}$ and mendicant friars ${ }^{139}$, and finally the persecution of witches during the later Middle Ages. ${ }^{140}$

131 Moore, Formation of a Persecuting Society; Nirenberg, Communities of Violence. Further discussion, e.g. in Frassetto, Heresy and the Persecuting Society.

132 See, e.g., Frakes, Contextualizing the Muslim Other.

133 See Geltner, Making of Medieval Antifraternalism, and Scase, Piers Plowman, engaging with Szittya, Antifraternal Tradition.

134 Goetz, Die Wahrnehmung anderer Religionen; Aurast and Goetz, Wahrnehmung anderer Religionen im früheren Mittelalter.

135 Sackville, Heresy and Heretics.

136 For a recent panorama, see, e.g., Simpson and Roach, Heresy and the Making of European Culture.

137 On the instrumentalizations of heresy, see recently Mercier and Rosé, Aux marges de l'hérésie.

138 See, e.g., Robinson, Authority and Resistance.

139 See Kerby-Fulton et. al., Pseudo-Hildegardian Prophecy; Steckel, Ein brennendes Feuer in meiner Brust, 152-160. 140 Utz-Tremp, Von der Häresie zur Hexerei. 
Other categories of intra-Christian polemics, especially anti-clerical and anti-monastic discourses, have also been studied for particular periods and regions, but mostly without specific reference to polemics. As a result, there is no clear picture of the trajectories of such critical discourses within Latin Christianity. Studies engaging with these particular strands of Latin Christian polemics often follow specific master narratives revolving around the beginnings of modernity, or rather, modernities: the Protestant Reformation and the many historical narratives organized around $i^{141}$ have provided the most important focus point for the analysis of confessional polemics, and by extension of late medieval anti-clerical, antifraternal and anti-monastic polemics which appeared to be their antecedents. ${ }^{142}$ Studies with a more regional orientation or a focus on vernacular literature often linked anticlericalism and critiques of the religious life to a »Renaissance « narrative, focusing on the emancipation of the laity from ecclesiastical direction (or, in literary terms, the emancipation of the vernacular languages from the Latin tradition). ${ }^{143}$ In firmly separate research fields, we find studies of eleventh- and twelfth-century "polemics of reform " (Thompson) ${ }^{144}$ targeting clerics, or on early controversies among religious orders. ${ }^{145}$ The relevant discourses are at times labelled "polemics", but remain unconnected to research on the later anticlerical traditions - even though there are clear similarities which suggest a common genealogy. ${ }^{146}$ Put together, this research would, in all probability, suggest that we witness a long-term episodic build-up of polemical vocabularies and rhetorics in Latin Christianity, at first primarily in Latin but from the thirteenth century onwards also in the vernaculars and increasingly in formats accessible to popular audiences. However, it remains to be ascertained how different religious conflicts - within the elites of the Latin church, between officials and heterodox movements, and between Christian authorities and Jewish or Islamic interlocutors - shaped this long-term development.

The problem of the geographical spread of different formations of cultural identities has been discussed much more explicitly. Older research tended to make fairly large-scale contentions about cultural differences - for example in arguing that medieval Islam was less invested, and in fact less interested, in confrontation with Christianity than the other way around. More recent studies have argued for a less essentialist approach, and scholars like Daniel König draw attention to the multiplicity of different observers within the ArabicIslamic world, some of whom were highly interested in parts and aspects of Christianity. ${ }^{147}$

141 On the fragmented historiography of the Reformations, see Walsham, Migrations of the Holy, 244-246.

142 See the critical remarks on this tendency in Geltner, Making of Medieval Antifraternalism and cf. e.g. Dykema and Oberman (eds.), Anticlericalism; Goertz, Antiklerikalismus und Reformation.

143 See, e.g., L'anticléricalisme en France méridionale.

144 I borrow this term from Thompson, Polemic of Reform, who nevertheless relates it to the period between the thirteenth and fifteenth centuries.

145 See, e.g., Coleman, Nasty Habits; Pearsall, Medieval Monks and Friars. A research project focusing on satire about monastic life during the fourteenth and fifteenth centuries is ongoing at the Technische Universität Dresden, led by Dr. Kai Hering.

146 If we view the similarities between anti-clerical discourses of the eleventh/twelfth century and later Middle Ages (see, e.g., Robinson, Authority and Resistance and Thompson, Polemic of Reform), genealogical links seem likely. Criticism of the monastic life seems to have a similar trajectory from the tenth and eleventh centuries to the fifteenth century, cf. Steckel, Satirical Depictions of Monastic Life.

147 On this debate, see König, Arabic-Islamic Views, esp. 14-26. 
We also have a number of excellent studies devoted to the culture of polemics developing in particular regions, first and foremost concerning Iberia, ${ }^{148}$ but also other regions like Hungary ${ }^{149}$ or Byzantium. ${ }^{150}$ Other studies have drawn attention to different genres and their perception of religious others. As Almut Höfert argues in her study of Christian views of the Turks during the fifteenth and sixteenth centuries, important shifts can be attributed to the rise of new observer perspectives, such as that of diplomats and of scholars developing an ethnographical rather than heresiological tradition..$^{151}$

As questions regarding the regional and chronological spread of patterns of religious identity and alterity can ultimately only be answered on the basis of comparative studies of larger or smaller remit, recent research has rediscovered an interest in cataloguing polemic, including the availability of various genres of polemic in manuscript form. ${ }^{152}$ Various research projects are currently assembling systematic overviews and databases of polemical corpora - either of certain types of polemics ${ }^{153}$ or of other materials pertinent to the study of religious encounter, such as legal texts on the status of religious minorities collected in the RELMIN project. ${ }^{154}$

\section{(5.) Debatable legitimacy}

If we move towards more scholarly polemical discourses, the modern critical definition of polemics as transgressive argumentation can be included in the list of potential characteristics of polemic. ${ }^{155}$ In an adapted formulation, we may say that polemical engagements could transgress the limits of legitimate argumentation or procedure in a given historical circumstance - and often triggered arguments over such limits.

For the study of medieval polemics, the modern understanding of the polemical as an essentially transgressive argumentation must be problematized - as discussed above, it imposes modern boundaries of legitimacy onto medieval discourses in a highly ahistorical manner, even though medieval polemics were organized by other considerations of legitimacy or transgressiveness than modern ones. Especially in religious polemics, it might, for example, be highly à propos to criticize an opponent with ad hominem arguments, for example in pointing out moral failings which discredited an opponent as hypocritical. To historicize this approach, we would, in essence, have to investigate the historical rules and boundaries of legitimate argumentation for every given polemical situation. Yet such an investigation would, in all probability, only show that historical actors tended to charge each other with transgressions of the legitimate boundaries of debate across all centuries, because they happened to disagree over these boundaries - or even consciously transgressed them to signal

148 See, e.g., Colominas Aparício, Religious Polemics of the Muslims; Herbers and Jaspert, Integration, Segregation, Vertreibung; Nirenberg, Communities of Violence; Nirenberg, Neighboring Faiths; Szpiech, Conversion and Narrative.

149 Berend, At the Gates of Christendom.

150 See the literature above and the contributions in Bonfil et. al., Jews in Byzantium; Tolan et. al., Jews in Early Christian Law; Speer and Steinkrüger, Knotenpunkt Byzanz.

151 Höfert, Den Feind beschreiben.

152 For a small-scale example of such a survey, see Soukup, >Pars Machometica in Early Hussite Polemic.

153 See, e.g., the Repertorium Operum Antihussiticorum, established by Pavel Soukup, www.antihus.eu/about.php (accessed 21.01.2018) or the Islamolatina project conducted by José Martínez Gázquez and others, grupsderecerca. uab.cat/islamolatina/ (accessed 21.01.2018).

154 See www.cn-telma.fr/relmin/index/ (accessed 21.01.2018).

155 See this definition, e.g., in Stauffer, Polemik, 1404; Cancik, Apologetik/Polemik, 33. 
the depth of their conviction.

As it happens, a comprehensive historicization of the cultural regimens governing the practice of historical communities of scholars has been advocated within the cultural history of learning anyway, and many case studies relating to debate culture have been produced. ${ }^{156}$ We can partially reconstruct the unwritten rules regulating various discourses and scholarly practices in circumscribed historical situations, if we acknowledge that such reconstructions describe cultural patterns which consciously abstract from the much messier, contradictory practices of historical actors. Several studies on the »boundary work« undertaken by medieval scholars have also shown that it is quite possible to detect specific short- and mid-term historical dynamics, in which actors attacked particular practices as illegitimate, gradually effecting changes in the rules of engagement dominating specific scholarly milieux. ${ }^{157}$

It is this transformative potential of polemical engagements, and not a postulated metahistorical transgressiveness, which indeed appears as an important characteristic of polemics. As Vincent Azoulay and Patrick Boucheron suggest, the large-scale polemical discourses developing in situations of sustained conflict often led to the formation and distinction of new communities of learning, at times even to the institutional consolidation of new disciplines. As they congenially put it, intellectual violence may appear as "foundational violence", which attacks an opponent, but also sets new boundaries of debate and opens up new areas of contention by force. ${ }^{158}$ Bénédicte Sère has recently developed this observation, pointing out that large-scale controversies in particular must be seen as prime generators of transformation. She therefore suggests an interdisciplinary history of controversies, which analyses practices of conflicts and controversies and the discourses generated by them, and reconstructs the different "polemical regimens" (régimes de polémicite) visible in them. ${ }^{159}$

Taking up the focus on "foundational« intellectual and symbolic violence, Sère highlights a first question to ask of historical polemical regimens, namely how pre-modern controversial discourses were bounded by institutional or situational constraints built on violence - practices of censorship, but also the threat of (judicial or extra-judicial) physical violence, or of exclusion, which made themselves felt in intra-religious as well as in inter-religious conflicts - if, of course, in different ways. ${ }^{160}$ This important nexus represents a prime dimension of inquiry for a history of religious polemics as part of a larger history of controversies.

To distinguish further possible areas of contention in historical debates generating different polemical regimens, it is helpful to analyse the distinction of three different ideal types of polemics suggested by Marcelo Dascal. ${ }^{161}$ Dascal first distinguishes a form of polemics labelled »discussion", in which participants concurred that their disagreement over an issue was based on some form of mistake, and sought for a solution allowing them to correct the mistake, ultimately remaining within a problem-solving framework. The conflict could then

156 For the late medieval and early modern period, see, e.g., Sère, Débats d'opinion; Piron, Écrire en aveugle; Bremer, Religionsstreitigkeiten; Gierl, Pietismus und Aufklärung; for the early and high Middle ages see, e.g., Monagle, Orthodoxy and Controversy; Giraud, Discours magistral.

157 See, e.g., the contributions in Mulsow and Rexroth, Was als wissenschaftlich gelten darf. The concept of »boundary work « elaborated in this volume builds on Gieryn, Boundary-work.

158 Cf. Azoulay and Boucheron, Violences intellectuelles, 31-32 (the reference to "violences fondatrices« on 32).

159 Sère, Introduction. See also Sère, Débats d'opinion, 9-15.

160 See Sère, Débats d'opinion, 13-15 and 351-410. See also her contribution in this volume.

161 Cf. Dascal, On the Uses of Argumentative Reason, 5-7.

medieval worlds $\bullet$ No. $7 \cdot 2018 \cdot 2-60$ 
be ended by a solution found through open-ended engagement. In "disputes", on the other hand, the contenders did not expect conflict resolution through a form of mutually agreed method, as their divergences were rooted in preference, feelings, or belief, and/or shared methods of solution were lacking. A conflict of this type takes the form of contest rather than problem-solving, and cannot be solved, but only »dissolved « by force, avoidance or disregard. In mixed-type "controversies", conflicts escalated to include both debatable issues and diverging beliefs or attitudes. This form of conflict follows a deliberative model and typically finds a "resolution" dependent on the social and political circumstances rather than a solution dependent on the application of a method alone. The contenders are therefore engaged in piling up different sorts of arguments and issues, hoping to "tilt [...] the sbalance of reason in their favour. ${ }^{162}$ Dascal also introduces ideal types of "moves « associated with each form of polemic: the "proof ", which aims to compel the opponent by force of truthful argument; the "stratagem «, which aims to cause or induce belief by overwhelming the opponent (and may even include deceit), and the "argument«, which aims to persuade. ${ }^{163}$

If we attempt to pinpoint the distinctions implicit in this model, at least three analytically distinct characteristics of "polemic" result, which will be separated in the following subheadings. The polarization inherent in polemical discourses may arise because of different views about the best methods for solving the issues at hand. It may also be tied to the circumstances of conflict resolution, arising where participants refuse to engage in open-ended debate, and either enter an argument with pre-determined standpoints or refuse to accept the result of a pre-determined procedure. Polemics may finally also result where opponents simply could not agree on a methodology or procedure for finding the truth, and disparaged each other's methods instead.

\section{(6.) Scholarly methods}

Polemicists could draw on established practices of debate or scholarly methods to elaborate their religious standpoints, or produce specific agreements and compromises regarding such methodologies. Many polemical exchanges take recourse to frameworks and norms established in scholarly settings, and, at times, such settings were negotiated beforehand by the polemical speakers and their opponents. Debates very often led to contestations of the method of discussion and, more importantly, of the textual basis for exchanges, for example in Christian-Jewish disputations of the thirteenth century. ${ }^{164}$

An illustration of the different potential levels of methodological debate can be drawn from a well-known and by now much-debated overview, in which Amos Funkenstein distinguished between four different types (and phases) of Christian anti-Jewish polemic. ${ }^{165}$ In our context, they can be summarized to highlight the pragmatic, factual challenges any scholarly engagement between religious traditions had to overcome. As a first type of anti-Jewish

162 Dascal, On the Uses of Argumentative Reason, 6.

163 Dascal, On the Uses of Argumentative Reason, 6-7.

164 On Jewish-Christian disputations generally, see the contributions in Limor and Stroumsa, Contra Judaeos; Szpiech, Medieval Exegesis and Religious Difference; as well as the literature cited above, notes 7 and 18.

165 Funkenstein, Basic Types of Christian Anti-Jewish Polemic. On the debate sparked by this typology, see, most recently, Berger, Jewish-Christian Debate. 
polemic, Funkenstein lists collections of authoritative citations and arguments culled from biblical and patristic texts, meant to help and support Christian disputants against their Jewish opponents. While this form of engagement largely saw each party drawing on its own scholarly tradition, a second type of polemic instead proposed basing itself on rational, philosophical argumentation, mirroring the shift in scholarly techniques visible in high medieval Europe to establish an (at least superficially) neutral, overarching base for discussion. A third type of Christian polemic attacked the Talmud and other Jewish postbiblical religious literature, crossing linguistic barriers and engaging with issues of text criticism in the process. A fourth type instead drew on the Talmud to attempt to prove that Jewish religious literature supported Christian messages, thus not only engaging with the normative texts of Judaism, but offering competing interpretations of this body of texts instead. Parallel research on other cultural constellations, such as Daniel König's observations on the complex passages visible in Islamic scholars' gathering of knowledge about Latin Christianity, also highlights the many cultural and pragmatic boundaries which had to be crossed in cultural encounters, quite independently of the question of "mental barriers" which might exist against other religions: ${ }^{166}$ Islamic scholars could often not be sure about the quality of information about Christian Europe that they managed to gather. There were multiple linguistic barriers to overcome, and problems of contextualization and interpretations of texts to solve.

Not least for this reason, the positive, culturally productive role of inter-religious polemical engagements and of intra-religious controversies for medieval intellectual exchange has often been emphasized. ${ }^{167}$ Howevermuch religious opponents might disagree, an engagement with competing philosophical and theological systems often forced them to make their own positions more explicit, to refine their methodological and epistemological stance, and at times even to systematize their own handling of authoritative bodies of texts or - especially in the case of inter-religious encounter - to engage in textual criticism concerning sacred or authoritative texts. ${ }^{168}$ Interreligious and intercultural encounter actually often led to a devaluation of the methods and texts used by the opponents, and should not be misunderstood as a typical situation prompting straightforward knowledge exchange. But there is a strong consensus that mutual irritations which prompted different religious scholars to engage with each other's viewpoints were one of the most important drivers of cultural transfer and scholarly innovation during the medieval centuries. ${ }^{169}$ The history of art, which shows closely entangled relationships, for example among Jewish and Christian artists and patrons, bears this out from a different perspective. ${ }^{170}$

166 König, Ausstrahlung - transkulturelle Datenmigration - Dokumentation, at 228; see in more detail idem, ArabicIslamic Views of the Latin West.

167 See recently, e.g., Lasker, Impact of Interreligious Polemic; Freudenthal, Arabic into Hebrew; from a systematic perspective Brentjes et. al., Towards a New Approach. For the role of contacts and conflicts in intra-Christian intellectual life, see Mews, Communautés de savoir.

168 See, e.g., Fidora, Latin Talmud; Ragacs, »Mit Zaum und Zügel«; Lazarus-Yafeh, Intertwined Worlds.

169 This assertion gains importance in the face of recent renewed attempts to appropriate medieval scholarly innovation exclusively for Western, Christian Europe. The case against this isolationist view has been made in the context of the controversy surrounding Sylvain Gouguenheim, cf. Büttgen et. al., Les Grecs, les Arabes et nous. On the dynamics of cultural transfer in inter-religious settings, see recently, e.g., Freidenreich, Beyond Religious Borders; Brentjes et. al., Towards a New Approach to Medieval Cross-Cultural Exchange.

170 See, e.g., Shatzmiller, Cultural Exchange; Kessler and Nirenberg, Judaism and Christian Art. 
As scholars focusing on concepts of religion and religious identities rather than on intellectual exchange have also emphasized, polemical engagements prove to be highly productive triggers for the formulation and explication of religious terminologies. ${ }^{171}$ This discussion has recently gained much ground. During the 1980 s, medievalists still had to rectify the assumption that the Christian Middle Ages had no specific terms for the plurality of "religions «, but tended to view all religious phenomena through an asymmetrical terminology distinguishing "true " Christian "faith " from heresies or superstitions. ${ }^{172}$ In the meantime, a series of publications have pointed out the use of concepts like Latin lex, religio and secta ${ }^{173}$ or Arabic din, which could all be used with or without disparaging connotations. An interdisciplinary study of polemics thus also emerges as a highly promising avenue for exploring medieval religious taxonomies with a view to further interdisciplinary discussion.

\section{(7). Pre-determined stances}

If we look at the patterns of conflict resolution, many polemical engagements - those which conform to Dascal's type of "dispute« or "controversy « rather than that of »discussion ${ }^{174}$ - lack open-endedness. This typically results from a pre-determined stance, as polemical speakers were convinced that they were already possessed of a truth.

This characteristic of polemic can be seen in most medieval inter-religious dialogues and in texts documenting disputations, in spite of their generally dialogic nature. ${ }^{175}$ Participants in inter-faith debates (which were, in any case, often restricted to the discussion of particular factual questions) would usually not treat such disputations as a problem-solving activity, but argued from a position of religious conviction. But at the same time, polemicists typically sought to demonstrate the intellectual superiority of their own faith, and their conviction is thus at times obscured by a strong reluctance to admit prejudice, or at least by the attempt to separate illegitimate prejudice from legitimate confidence in one's own position. Religious disputations were thus intriguing hybrids of intellectual battle and appeals to divine judgement: as in the medieval judicial ordeal, in which God was understood to give the victory to the champion of the deserving side, the discussant had to engage in actual battle while also trusting that truth would prevail. As many studies have pointed out, the representation of scholarly debates in disputation texts actually drew much of its persuasive force from this tension. The narrative arc of intellectual battle (or, in dialogues, of didactic instruction) was used to present highly constrained situations as open-ended discussions, and to assert the victory of one side even where the results of an encounter remained highly contentious. ${ }^{176}$

171 See, e.g., Palumbo, From Constantine the Great to Emperor Wu; Stünkel, Una sit religio; Hasselhoff and Stünkel, Transcending Words.

172 On this debate, conducted from the 1980 s onwards, see Biller, Words and the Medieval Notion of Religion.

173 Besides the literature in note 171, see Weltecke, Religion vor der Religion; Glei and Reichmuth, Religion between Last Judgement, Law and Faith; Tischler, »Lex Mahometi«; Hasselhoff, Huldrych Zwinglis Verständnis von religio.

174 Cf. Dascal, On the Uses of Argumentative Reason, 5-6.

175 On the characteristics of inter-faith and religious disputations, see generally Novikoff, Medieval Culture of Disputation, 172-221; Weijers, Queritur utrum; Limor, Polemical Varieties; Ragacs, Reconstructing Medieval ChristianJewish Disputations.

176 Not only Jewish-Christian disputations but also intra-Christian debates might, therefore, result in several contradictory representations of the outcomes. For an example of the latter, see, e.g., Pietsch, Junge Republik, 271-278. 
If we have no external sources allowing us to reconstruct an instance of controversy, it may be impossible to determine whether a polemicist viewed an engagement as open-ended or brought a pre-determined stance to it. Where such external sources exist, they offer the highly intriguing possibility of tracing the escalation patterns of polemical engagements, which might devolve from open-ended, problem-solving discussions to more complex deliberations and finally to acrid disputes. Yet this distinction forces us to pay close attention to the nuances of polemical argumentation, and to describe transitions from didactic or disputational situations to less regulated conflicts, which would usually overflow the confines of particular institutional settings to address larger publics, and finally to public debates using disparagement as well as scholarly arguments. As will be discussed further in the concluding sections, an interdisciplinary approach to the analysis of patterns of escalation and polemical mobilization therefore seems particularly important.

\section{(8). Epistemological asymmetries}

Polemical engagements frequently produced epistemological asymmetries of some form. Especially in situations in which no pre-agreed method or procedure of truth- or fact-finding existed, polemicists often insisted on the superiority of their own method, procedure or overall epistemological assumptions.

This asymmetry could simply be established in rhetorical gestures or, to use Dascal's term, by way of stratagem. ${ }^{177}$ Southcombe, Suerbaum and Thompson observe how a polemical speaker at times "claim[s] [...] authority to represent the just cause, or (circularly), by articulating unquestionable propositions, establishes authority to speak. ${ }^{178}$ Many references to rational argument used in polemics, for example, turn out to bolster the authority of the speaker, and add little rationality to the argument. David Berger shows this for various references to rational argumentation deployed by high medieval Christian authors against Jewish interlocutors - as these rational arguments often transported known points drawn from authorities, they were essentially "window dressing $"{ }^{179}$ Cédric Giraud observes such symbolic functions of scholarly language among high medieval Christian scholars even outside of inter-religious polemics: the very vocabularies of argumentation current in the high medieval Latin Christian schools often transported implicit assertions of authority. ${ }^{180}$ As Ryan Szpiech points out using the example of the converted Jew Abner of Burgos/Alfonso of Valladolid ( $\dagger$ c. 1345/47), the authorization of a polemical speaker might also gain considerably if he was able to present rhetorical strategies of authorization and authentification which conformed closely to the patterns expected by the audience. ${ }^{181}$

In other cases, polemical speakers elaborated more complex theoretical positions in engaging with religious opponents, explicating their own methodological or epistemological stance. ${ }^{182}$ Though this might (as discussed above) lead to important impulses, many medieval polemicists in fact constructed highly harmful asymmetries. This was largely overlooked by

177 Dascal, On the Uses of Argumentative Reason, 6-7.

178 Southcombe et. al., Introduction, 6.

179 Berger, Jewish-Christian Debate, 126.

180 Giraud, Discours magistral, parole d'autorité; cf. Destemberg, Espace public, at n. 16-19.

181 Cf. Spziech, Conversion and Narrative, 145-154.

182 A popular example is Thomas Aquinas' Summa contra gentiles, see, e.g., Lutz-Bachmann, Rationalität und Religion. 
twentieth-century intellectual historians like Southern, who were happy to celebrate the apparently growing rationality of Christian inter-religious engagement during the twelfth century, and classed it as an instance of the modernity of the medieval West. Anna Sapir Abulafia and others, by contrast, showed how the heightened claims towards rationality uttered by medieval Christian authors also led them to the conclusion that Jews were irrational and, in fact, even obdurate, so that the use of intellectual engagement with them became doubtful. The insistence on human rationality as a way towards faith - which formed an important part of the high medieval humanism fêted by Southern - even led medieval Christian authors like Petrus Venerabilis to doubt the very humanity of Jews. ${ }^{183}$ This construction of a systematically asymmetrical epistemology, which appropriated rationality and scientific principles for Christianity, and skewed theoretical views of the processes of cognition towards the Christian message, thus emerges as a dark underbelly of high medieval rationalism.

\section{Conclusions: Reconstructing patterns of embedding and escalation of polemics across cultures and genres}

So far, this article has surveyed some of the different accentuations given to the concept of religious polemics in different research traditions, and has suggested a preliminary breakdown of various constituents or dimensions of polemical discourses. Given the extreme complexity of the topic and the very broad range of different phenomena assembled under the umbrella term of "polemics", one may well pause briefly to ask whether any further clarification and operationalization will actually be useful. Couldn't we simply avoid the term and start afresh with studies on »invectivity« or »hate speech» on one side, and »(inter-)religious encounter" on the other?

In answer to this rhetorical question, one may state that terminological distinction is certainly one pragmatic strategy to counter the ambiguities and complexities of the term "polemics". Scholars studying inter-religious debates may prefer to speak of religious controversies (understanding that these may, under their respective polemical regimens, include elements of disparagement or violence) or of the construction of religious difference and diversity. Scholars interested in forms of disparagement of other religious groups may be better off with an exclusive focus on different historical forms of aggressive rhetoric, or "invectivity", or even take up the contemporary label of "hate speech". These two research themes - of religious controversy with its polemical regimens and of invectivity - indeed appear as the two main centres of gravity within the interdisciplinary research field. Both offer themselves for further comparative research, especially for transcultural comparisons, which juxtapose culturally separate but similar phenomena in order to refine our view on them and tease out the different cultural nuances. ${ }^{184}$ Pursuing such broadly comparative perspectives indeed appears in order if we hope to push the interdisciplinary boundaries further out and include a (geographically and chronologically) broader range of different historical polemics.

183 Cf. Abulafia, Christians and Jews in the Twelfth-Century Renaissance; eadem, Christians and Jews. 184 Höfert, Europa und der Nahe Osten. 
Yet something would be lost if we focused only on scholarly polemics, or only on invectives, or only on inter-religious encounter, and three research fields which encourage a broad approach to polemical traditions in all of their variety can be described with a little more clarity at this point. In these concluding observations, the contributions making up the thematic section in this volume, which ask particularly how texts or situations "verged on the polemical « within the Latin Christian tradition, will be used to furnish some examples. ${ }^{185}$

Firstly, the study of religious polemics continues to be of interest as part of a "cultural history of controversy «, as Jean-Pascal Gay and Bénédicte Sère put it. ${ }^{186}$ The investigation of polemics is a particular form of the study of conflict, which has long proved to be one of the most privileged and fruitful methodological perspectives available within the theoretical framework of cultural history. The modern term »religious polemics" actually puts the spotlight on a highly charged communicative interface between different societal spheres: in investigating religious polemics, we ask how religious identities - and thus cultural hierarchies - were imagined and expressed, either in a given moment or over longer periods. But at the same time, we ask about the categories of description and the techniques of rhetorical persuasion employed by polemicists to convince different audiences of their stance, and about the relations they postulated between religious truths and the intellectual methods of explicating them - and at times also between religious truths and economic, political, or legal norms.

Where the sources allow us to draw these threads together, the study of religious polemics offers an intriguing point of historical observation, which allows us to reconstruct mid- and long-term transformations resulting from culturally productive tensions. One such tension exists between polemical writings and philosophy, theology, and political theory: ${ }^{187}$ As Bénédicte Sère's contribution in this volume shows, for example, large-scale debates like the one rocking the Latin church during the Great Western Schism (1378-1417) could lead to very distinct renegotiations of the reach of intellectual analysis in solving the problems of political hierarchy. In negotiations determining whether scholars were allowed to debate the limits of papal power, and in power politics which established intellectual or physical constraints on the activity of scholars, such controversies realigned the relationship of scholarly expertise, religious authority and political power to produce new cultural constellations, which were, in turn, mirrored in changing polemical regimens.

A second area of investigation concerns the spread of polemical discourses within specific historical societies. As stated in the introduction, we know that the term "polemics" encompasses a whole range of textual and visual genres ranging from the most elaborate scholarly engagements to the coarsest disparagements, and we know that we often find elements of polemical argumentation embedded in texts or images not primarily aiming at religious confrontation. Yet we have no clear, cross-disciplinary typology of such semi-polemical forms, and no clear terminology for studying the way polemical traditions permeated medieval societies.

185 It should be noted that these contributions are used to make particular points and cannot be summarised in full. 186 Cf. Gay, Lettres de controverse; Sère, Introduction, at n. 1.

187 See, e.g., Lasker, Impact of Interreligious Polemic, 122. For the Christian area, see, e.g., the observations by Marmursztejn, Autorité des maîtres. 
One strategy for exploring the range of different text types which may contain polemical elements is to follow up the textual (or visual) reception of polemical traditions, and to study the way different genres and their pertinent rhetoric intermingled. Reima Välimäki's article in this volume illustrates the spread of specialized polemical material into more popular didactic genres on the fundamental level of materiality and linguistic transmission: he discusses how a Latin polemical text dealing with heretical Waldensians, Petrus Zwicker's Cum dormirent homines (1395), was translated into the vernacular (Early New High German) and subsumed in all its parts into a catechetical encyclopedia aimed at laypeople by Ulrich von Pottenstein ( $\dagger$ 1417) about fifteen years later. As Välimäki highlights, this process of translation also led to changes. Often, these were explications and clarifications of aspects which remained largely implicit in the Latin original. But Pottenstein also added some emphases - for example in attacking bad clerics, whose faults contributed to the heretics' success. The inclusion of all parts of an anti-heretical treatise into an essentially didactic text, which fits into the well-known fifteenth-century tendency of providing more elaborate theological education for the laypeople, ${ }^{188}$ is also intriguing. As Välimäki points out, we do not know enough about the relationship between polemical and catechetical texts for the later Christian Middle Ages, nor probably for other cultures.

In Justine Trombley's contribution, we find another instance of polemical elements becoming embedded in other genres, though this time, the direction is reversed: her analysis engages with the "Mirror of Simple Souls", a work authored by the beguine and mystic Marguerite Porete, which continued to circulate anonymously after Marguerite had been burned at the stake at Paris in 1310. As Trombley shows, there were rather different strategies for refuting this text. While some extant refutations remained completely within the framework of scholarly techniques of identification of errors, simply listing articuli containing errors and the authorities necessary to refute them, one treatment engages rhetorically with the anonymous work. Moreover, as Trombley points out, this narrative attack on the "Mirror" made use of a whole repertoire of different rhetorical strategies, drawing on different anti-heretical traditions using arguments and authorities, but also disparaging categories and highly emotional rhetorical appeals. Though the exact background of this anonymous attack must remain unclear, the text throws up many questions about authorial intentions, possible audiences, and typical patterns of polemical rhetoric in its day: was the author experimenting with different styles - or perhaps embedding a different rhetorical pattern of polemical engagement, such as sermon rhetoric, into a text originally meant as a theological refutation or consilium? A comparative approach might furnish a much better framework for making such judgments, and for refining the distinctions underlying them.

Better knowledge about the diffusion of polemic would also provide a better basis for other comparative questions, for example concerning patterns of escalation in religious conflict. In this instance, differences between inter-religious and intra-religious conflicts play a significant role. Between faith communities like Jews, Muslims and Christians, religious difference was already established, while various intra-Jewish, intra-Islamic or intra-Christian conflicts needed to construct this difference in the course of conflict escalation. Melanie Brunner's contribution in this volume provides the rare example of an intra-religious conflict escalation beginning almost from scratch, reconstructing the rhetoric accompanying 
the split of the religious order of the Friars Minor or Franciscans into the factions of the radical so-called Spiritual Franciscans and the Community around 1300. As Brunner shows, this conflict created polarizing argumentative schemes of "good" and »bad" Franciscans, contributing to the development of diverging religious identities within the Order. But the treatises also linked the difference of the respective »bad « side to the concept of heresy, making use of established repertoires of anti-heretical argumentations and disparaging rhetoric, for example in calling their opponents heretics and hypocrites.

Several interesting functions of this inscription of the debate into a pre-existing polemical tradition stand out: we may note that the ascription of heresy seems to have a signalling function in a conflict which was in the process of shifting from the clearly defined decisionmaking structures of the Franciscan order into a broader public, consisting of the order's friars but also political and legal decision-makers, now addressed by the competing argumentative treatises hoping to sway their opinion. Read closely, even the driest polemical arguments therefore not only made legal points, but also worked on a level of symbolic communication appropriate to this public space, much like the physical gestures which would have accompanied trajectories of escalation or breakdowns of communication in a face-to-face conflict in the political sphere. ${ }^{189}$ Warning the opponents that they were falling into heresy was not only a legal argument, but amounted to the rhetorical drawing of a line in the sand, marking particular contentious points and signalling the speaker's refusal to compromise. It might, therefore, be interesting to ask how far such polemical rhetoric may be correlated to patterns of public debate common in political sphere. Other Franciscan borrowings from older polemical discourses actually show that the polemical escalation drew on a whole underlying taxonomy of religion, which formed the basis for relational ascriptions of religious difference. As the Franciscans were deeply engaged with the church's battle against heresy, accusing them of heretical behaviour - and thus linking them to their most particular symbolic "other" - also implied that they had not only violated, but inverted the value hierarchy upon which the order was predicated.

In polemical rhetoric formulated by Christians against Jews or vice versa, such relational argumentation may also be present, as will become clear in a moment. But it seems obvious that much Christian polemic against Jews uses different techniques of escalation - mainly because religious difference was already established, but also because the relevant polemical discourses belonged in different contexts and spoke to different audiences. Birgit Wiedl's contribution on the amical relations and polemical engagements with Jews visible in Christian business documents presents us with highly interesting findings in this respect. Business documents like charters are intriguing cultural interfaces which illustrate the closely entwined social worlds of Christians and Jews. As Wiedl shows, many of them document close contacts and respectful alliances. Yet occasionally they contain polemical attacks, and at times allow us to draw conclusions about the deep-seated suspicions which Christians harboured against their Jewish business partners, and which Christians embroiled in business conflicts might attempt to instrumentalize. Wiedl's cases clearly document how the presence of a pre-existent, broadly established polemical discourse against Jews made it possible for such Christian authors to generate resentment and sway their audiences with minimal rhetorical effort, as they could rely on their Christian interlocutor's collective memory to supply negative associations. In one law case we thus find a complaint among neighbours 
concerning noise and smell referring to a »Jewish stench «. This clearly sought to trigger a physical reaction of disgust and anger. Similarly, an ecclesiastic lamented about being caught in an "abyss of usury " by his Jewish creditors. Even though the debts in question were incurred in completely legal circumstances, this reference to usury, linked by association to injustice and transgression of moral norms, could apparently be relied on to mobilize other ecclesiastics to come to his aid.

Claudia Daiber's contribution on the fifteenth-century anti-Jewish Fastnachtspiel »Von dem Herzogen von Burgund « makes the other, missing half of such polemical strategies visible: the religious drama analysed in her article literally seems to try to put the full repertoire of anti-Judaist and anti-Semitic theories, stereotypes, and rhetoric onto the public stage, providing the Christian community with an emotionally charged rehearsal and a boiled-down theological legitimation of the negative stereotypes against Jews, laying the groundwork for brief evocations of resentment such as the ones encountered by Wiedl. Though we know nothing about the circumstances which might have accompanied such a staging, the play authored by the layman Hans Folz († 1513) again illustrates how elements of anti-Jewish polemics might be transformed by their translation into the vernacular, and in this case, also into the popular format of a Shrovetide play. The play pulled out all the stops to make a tangible, emotional, and fully lived reality out of the theological arguments and literary tropes concerning Jews. It included a staging of the allegedly evil, grasping nature of the Jews who were shown to physically crowd and threaten the Christians on the stage, a coarse, humorous rendition of the false Jewish Messias, and a live appearance of the iconic Judensau. As Folz's social contacts tie him to the Nuremberg business elite, who were highly interested in removing the competition constituted by the Jewish communities, we again glimpse the mutual instrumentalization of religious difference and business interests already emphasized by Wiedl.

The contrast between this situation and the polemics exchanged between the factions of the Franciscan order seems marked, and it would indeed be highly problematic to subject such different forms of religious encounter to a schematic comparison. The long-term relations between Christians and Jews, who lived in the midst of Christians in a highly precarious position, and accumulated a complex tradition of polemics as their paradigmatic religious other over the centuries, must, of course, be seen as one of a kind. Yet there are comparative questions that allow us to sharpen our heuristic tools, and may, therefore, still be asked. Returning to the intra-religious conflicts surrounding the religious order of the Franciscans, we might, for example, ask whether the polemics exchanged by and about them could not also draw on well-established discourses already present within the collective memory. In some respects and to a limited degree, this seems to be the case. One notable feature of the exchanges between the Spiritual and the Community Franciscans for example consists in the accusation of hypocrisy. On one side, this was another highly traditional disparagement, borrowed from well-established anti-heretical rhetoric, which had been distributed by the preaching of the Franciscans and of other mendicant orders since the early thirteenth century. ${ }^{190}$ But, more than this, the accusation of hypocrisy was also a prime charge laid against the Franciscans (and other mendicant orders) by their long-term rivals and competitors, the secular clergy, who had been involved in public, at times highly aggressive controversies with the Franciscans for decades, and had borrowed the charge of hypocrisy from anti-heretical 
polemic to construct a new polemical strand of anti-mendicant or anti-fraternal polemic. ${ }^{191}$ If some Franciscans now joined these arch-competitors in calling some of their brothers hypocrites, this implied not only that these brothers had betrayed their order by conforming to the outsider's worst expectations; it also signalled that the accusing group was ready to side with the order's enemies to incriminate the deviants.

This is not only another instance of a relational construction of difference. The accusation of hypocrisy was also perhaps the most relevant element of the thirteenth-century controversies between secular clergy and mendicant orders which had entered vernacular discourses, for example in political poetry and in the sophisticated but popular Roman de la Rose of the 1280 s, which embodied hypocrisy in the allegorical figure of "False Seeming", a sly trickster who took on various religious habits. ${ }^{192}$ While the references to hypocrisy in the polemics between Spiritual Franciscans and Community may only have the most tenuous links to this discourse, it was highly present in other polemical engagements between the mendicant orders of the Dominicans and Franciscans, the laypeople and the clergy during the thirteenth, fourteenth and fifteenth centuries. ${ }^{193}$ Spread through a combination of theological polemics against hypocritical friars, monks, nuns or clergy, and of literary texts and stories diffusing these arguments together with adjacent stereotypes and typical complaints in the vernacular, this discourse enabled brief and evocative polemical argumentations, similar to those visible in Wiedl's anti-Jewish outbreaks in business texts. In the decades around 1300, for example, we encounter several instances of popular protest and even some instances of (comparatively circumscribed) violence against friars, which broke out when participants in legal conflicts, primarily inquisition trials, managed to mobilize popular feeling against the mendicant inquisitors by polemicizing against them, stressing conventional anti-clerical and anti-mendicant tropes of religious hypocrisy, greed for money, and sexual transgression. ${ }^{194}$

Altogether, the complex Jewish-Christian relations and the tangled strands of intraChristian polemical discourses might thus furnish interesting comparative horizons for each other - but to develop this perspective, we would first have to overcome the fragmentation of different research fields, and then to investigate the connections between different strands of Christian anti-heretical, anti-clerical, anti-monastic and anti-fraternal polemics.

In a next step, such an integrated, comparative perspective could be developed further by also investigating the links between intra-religious and inter-religious polemics - a third research field which awaits a more systematic exploration. A first, general question which has not been asked systematically concerns the differences between intra-Christian polemical discourses (including anti-heretical polemics) and inter-religious polemics. As extant research suggests, they were different - but there were a number of identical or closely linked arguments, images, and stereotypes, as most polemical discourses within Christianity sooner or later became entangled through transfers and adaptations of particular arguments or rhetorical and artistic styles. This highlights the problems we create when we apply the modern concept of "religion" to the pre-modern period: within medieval societies, people did not encounter Jews, Christians, Muslims, heretics, bad clerics, or simply impious people separately and without linking them. On the contrary - especially in making polemical remarks

191 Cf. Geltner, Making of Medieval Antifraternalism; Steckel, Falsche Heilige.

192 See Emmerson and Herzman, Apocalyptic Age of Hypocrisy, and cf. Huot, Romance of the Rose.

193 See, e.g., Bruschi, Falsembiante-Inquisitor; Scase, Piers Plowman; Geltner, Making of Medieval Antifraternalism. 194 The paradigmatic case of Bologna 1299 is described in Thompson, Lay Versus Clerical Perceptions of Heresy. 
about representatives of different groups, they frequently created overarching taxonomies of religion and linked these to criteria of good or bad religiosity, creating a practical, messy, and highly heterogeneous discourse on "religion". If we aim for further clarifications of the conceptualization of »religion « and religious diversity during the medieval centuries, and if we hope to reconstruct how religious difference was discussed within different social groups and media, this practical, polemical discourse concerning religion appears highly relevant.

To investigate this discourse fully, however, we need to cut across the boundaries of the research fields of religious encounter on one side, and intra-religious dynamics on the other, and ask how the medieval discourses concerning the relevant entities were linked. In practice, we might, for example, ask how intra-religious conflicts made use of inter-religious polemics - for example in polemical comparisons which linked members of one one's own group to various religious others.

Especially if we count "heresy « as a separate religious group, this technique is surprisingly widespread within Latin polemics. We not only encounter Franciscans calling their errant brethren heretics, but a whole spectrum of different forms of polemical comparisons and identifications which linked different religious groups and thus implicitly constructed religious taxonomies.

Andra Alexiu's contribution to this volume, on Hildegard of Bingen as a polemicist against "false teaching ", shows several variants of comparison as a polemical technique. Hildegard's text (in letter form, but based on a sermon) constructed a complex landscape of religious difference by way of different comparative operations. Hildegard's admonition contains some outright comparisons linking her addressee, the lax Christian clergy of Cologne, to different religious others: the ideals of the biblical past, some negatively connotated biblical groups such as the Sadducees, as well as the unavoidable animals (here scorpions). But Hildegard also built a relational argument on a large-scale comparison of clerics and (Cathar) heretics, ultimately in a manner similar to the Franciscan polemics analysed by Brunner. On one side of a double juxtaposition, Hildegard confronted the bad teaching of the lax, morally compromised clergy of Cologne with biblical examples of good teaching and her own role as a "teacher of teachers". On the other side, she introduced the threatening image of present and future groups of heretical "false teachers « descending on the town with the intent of corrupting the laity, particularly the women, and supplanting the clergy. A long comparative passage then points out the differences in behaviour between clergy and heretics: the false teachers are supported by the devil and possess evil supernatural powers, providing them with the strength enabling a strict ascetic life and absolute chastity. The current, underperforming pastors, by contrast, fall into moral corruption, allowing themselves to be surpassed by the heretics. The moral order is thus completely reversed, putting the church in grave danger.

In this text, a multi-way taxonomy of religious groups becomes visible, which ranges from the biblical Sadducees via two different groups of heretics (the present-day Cathars and a future group of "hypocrites « announced as harbingers of the Antichrist) to the present clergy, subdivided into laudable and corrupt. As Alexiu emphasizes, Hildegard's prophetic voice, presenting itself as an authority figure located on a meta-level, also manages to position itself at the top of the proposed hierarchy.

As in the Franciscan polemics discussed by Brunner, the primary polemical comparison that of clerics/Franciscans with heretics - creates its effect by linking the religious ingroup to the outgroup, and inverting the usual hierarchy. Bad clerics were not just violating norms, but subverted the cultural hierarchy by falling below the moral standard of heretics and thus 
transgressing the very boundaries of Christianity. Similar effects could be generated by other comparisons: Christian reformers engaging in hostilities with high medieval heretics at times likened them to Jews. ${ }^{195}$ Critics of the monastic orders, such as the Welsh cleric and courtier Walter Map († c. 1210), who engaged in a series of conflicts with the reformed monastic order of the Cistercians, also compared them to Jews. ${ }^{196}$ The comparison with Judaism was later enlarged by Martin Luther to encompass and disqualify the whole lifeform of regulated, monastic or mendicant orders. ${ }^{197}$ Both Judaism and Islam furnished polemical comparisons in debates between secular clerics and mendicant friars. ${ }^{198}$ In the conflict between the supporters and opponents of the reformer Jan Hus ( $\dagger$ 1415) in fifteenth-century Bohemia, the conflict party supporting the papal side was disparaged as the "Muslim party $«{ }^{199}$ Yet so far, we only have tentative and small-scale investigations of such comparisons - even though they seem surprisingly widespread, for example in didactic genres, which at times contain admonitory comparisons of bad Christians to Jews, Muslims or heretics. ${ }^{200}$

Such isolated polemical passages are typically not at the centre of attention in the study of polemics. Often, they are brief, almost throwaway references, which convey nothing new. But if we hope to understand the way polemical discourses became embedded in society, they nevertheless form an intriguing subject. While such comparisons could, of course, easily be explained away as stereotyped instances of othering, which have little to say, several cases imply that the relevant comparisons, albeit highly polemical, nevertheless constitute religious comparisons, and thus form part of the emergence of overarching evaluative discourses on religion and religious diversity.

Though such polemical comparisons do not use the scholarly, ethnographic or heresiological lens usually studied by scholars interested in comparative religion (a fact which typically leads to their omission in the specialized study of religious comparisons ${ }^{201}$ ), they nevertheless document how medieval authors linked different religions. ${ }^{202}$ Though stereotyped, such polemical attacks often resulted from very tangible dynamics of religious pluralization, as Hildegard's polemical juxtaposition of lax clergy and morally superior heretics illustrates. The heterodox groups which so threatened the high medieval church often, indeed, represented a better version of the clergy, and laypeople were highly interested in comparing them. It might thus be worthwhile to ask in a comparative perspective where and how these and other forms of polemical comparisons occurred, what polemical contexts we find them in, and what they can tell us about medieval perceptions of religious diversity and religious hierarchies.

195 Cf. Berger, Christian Heresy and Jewish Polemic, 210.

196 Cf. Walter Map, De Nugis Curialium, ed. James et al., d. 1, c. 25, 85-113 (comparing the Cistercians to the biblical Hebrews, but with polemical overtones pointing towards contemporary Jews).

197 Stamm, Luthers Stellung zum Ordensleben, 114-118, esp. n. 46.

198 See, e.g., the sermon documented in Bataillon, Intervention maladroite, and the implicit comparison in Henry of Ghent, Quodlibet XV, ed. Etzkorn and Wilson, 147-154, at 152-153. I am currently preparing a study of both texts. 199 Cf. Soukup, 'Pars Machometica in Early Hussite Polemics.

200 For an example, see, e.g., Von Karajan, Buch der Rügen, with polemical comparisons at 46 (1l. 28-37, Jews and Pagans) and 64 (ll. 659-665, Jews).

201 For this view of medieval polemical comparisons cf. Von Stuckrad, Religionsvergleich. 202 On this aspect of polemical comparison, see the remarks by Cavarzere, A Comparative Method. 
Intriguingly, we also find parallel polemical strategies in other cultural traditions, so that a transculturally comparative perspective is an option. Both Jewish and, presumably also, Islamic polemicists at times attacked Jewish or Islamic opponents by comparing them to Christians, heretics or unbelievers. ${ }^{203}$ In a responsum concerning the dissolvability of a marriage involving an ill woman, for example, the famed Jewish scholar Rashi († 1105) judged that it was not merciful to cast out a marriage partner who was ill, especially in the particular case in question, concerning a woman who only had a small rash. As Rashi added, the man attempting to get rid of her showed himself to be "not of the seed of our father Abraham", as he fell below a standard of merciful behaviour even upheld by those who denied God, i.e. the Christians. ${ }^{204}$

Just like Hildegard's unfavourable comparison of the lax clergy with pious heretics, this brief remark suggests a cultural horizon in which different religious behaviours were highly comparable. As there was room for genuine debate concerning divorce and illness in Christian legal norms concerning leprosy, ${ }^{205}$ one even wonders whether Rashi's offhand remark indicates that he was observing an actual Christian debate from a distance. In any case, Jewish polemicists usually constructed a sense of superiority by commenting on the lax morals of Christians ${ }^{206}$ - but as Rashi's responsum shows, the implicit hierarchy which demanded that Jews should surpass Christians could also be inverted to admonish co-religionists.

The investigation of such polemical comparisons in a connected and comparative perspective, looking both for transfers, influences and parallel occurrences of similar phenomena, might not only explore one technique of polemical rhetoric. The study of comparisons, a fundamental cultural practice of establishing identity, difference, and hierarchy, might also tell us something about the way medieval people connected, compared and ordered different forms of religiosity. As both Hildegard's and Rashi's comparisons show, moreover, such polemical comparisons actually debated issues, such as the chastity and moral life of the clergy, or the handling of illness, and were not just confrontations between one religious group and an incriminated, devalued other. The presence of three-way constellations - good Jews, bad Jews and Christians, or good clerics, bad clerics and heretics - gives us a stronger sense of the importance of the tertia comparationis of the underlying debates.

In conclusion, it is to be hoped that the exemplary questions and perspectives discussed in this last section can show that there is still much to be gained by bringing new impulses to the long-standing traditions of research on religious polemics. The necessarily narrow focus of this contribution, which clearly betrays its author's central interest in Latin Christianity, may even, rather inadvertently, have uncovered something of a gap in research: while scholars investigating religious encounter within the Mediterranean world have forged ahead and created an interdisciplinary research field focused on the contacts and polemical confrontations between Jews, Christians and Muslims, the study of polemics among the

203 Excepting research on the application of the heresy/unbelief label (see notes 13-16 above), literature dealing specifically with polemical comparisons within Judaism and Islam seems scarce.

204 I would like to thank Professor Regina Grundmann for pointing this reference out to me. I use the German translation in Von Mutius, Rechtsentscheide Raschis von Troyes, at 2:130-131 (quotation of German translation: "nicht vom Samen unseres Vaters Abraham«, 130).

205 See, e.g., Miller and Nesbitt, Walking Corpses, 106-110.

206 See, e.g., Berger, Introduction, 96-99. 
multi-centred world and highly diverse religious elites of Latin Christianity hasn't been able to keep up completely. The central Middle Ages may have drawn substantial interest, and extant research has pointed out some of the most important dynamics of cultural entanglement between concepts of heresy, Islam, Judaism and religious orders, but many nodes and twists of the tangled strands of polemics between heterodox and orthodox Christians, good and bad monks and clerics, and their similarities to Jews, Muslims or Pagans still remain to be explored.

Engaging with this research field of intra-Christian diversity might also, moreover, give added impulses to a global perspective on religious polemics. As Antonello Palumbo recently pointed out, we do not only observe encounters between different religions and forms of religiosity in pre-modern Asia. Rather, we find constellations in which polemical discourses between faith communities (such as Buddhism, Taoism and folk religion practices) intersected with internal dissensions within these communities. ${ }^{207}$ Developing a holistic approach to such constellations of religious diversity, which includes both inter-religious and intrareligious polemical discourses, might thus actually give fresh impulses to several of the fields involved. Ultimately, developing a comparative and connected perspective, even just on those regions we already feel familiar with, would not only contribute to the study of religious polemics, but also furnish important materials to an emerging global history of forms of religious diversity.

\section{Acknowledgements}

This research was undertaken within the framework of the Dilthey Fellowship research project "Diversitas religionum. Thirteenth-century foundations of European discourses of religious diversity«, supported by a joint initiative by the Volkswagen Stiftung and the Fritz Thyssen Stiftung. 


\section{References}

\section{Primary sources}

Bernard Gui, Practica inquisitionis heretice pravitatis, ed. Célestin Douais (Paris, 1886).

Henry of Ghent, Henrici de Gandavo Quodlibet XV, ed. Girard Etzkorn and Gordon A. Wilson, Ancient and Medieval Philosophy Series II 20 (Leuven, 2007).

Jan Hus, Magistri Iohannis Hus Polemica, ed. Jaroslav Eršil, Gabriel Silagi and František Šmahel, Opera Omnia 22 (Turnhout, 2010).

Walter Map, De Nugis Curialium - Courtiers'Trifles, ed. Montague Rhodes James, Christopher Nugent Lawrence Brooke and Roger Aubrey Baskerville Mynors, Oxford Medieval Texts (Oxford, 1983).

Secondary literature

Abulafia, Anna Sapir, Christians and Jews in Dispute: Disputational Literature and the Rise of Anti-Judaism in the West (c. 1000-1150) (Aldershot, 1998).

Abulafia, Anna Sapir (ed.), Religious Violence Between Christians and Jews: Medieval Roots, Modern Perspectives (Basingstoke, 2001).

Abulafia, Anna Sapir, Christian Jewish Relations 1000-1300: Jews in the Service of Medieval Christendom, The Medieval World (London, 2012).

Adang, Camilla, Anșārī, Hasan, Fierro, Maribel, and Schmidtke, Sabine (eds.), Accusations of Unbelief in Islam: A Diachronic Perspective on Takfir, Islamic History and Civilization. Studies and Texts 123 (Leiden, 2016).

Adang, Camilla. Hypocrites and Hypocrisy, in: Jane D. McAuliffe (ed.), Encyclopedia of the Qur'an, vol. 2 (Leiden, 2002) 468-472.

Althoff, Gerd, Gefühle in der öffentlichen Kommunikation des Mittelalters, in: Claudia Benthien, Anne Fleig, and Ingrid Kasten (ed.), Emotionalität: Zur Geschichte der Gefühle, Literatur, Kultur, Geschlecht 16 (Cologne, 2000) 82-99.

Altschul, Nadia R., Postcolonialism and the Study of the Middle Ages, History Compass 6/2 (2008) 588-606.

Ames, Christine Caldwell, Medieval Heresies: Christianity, Judaism, and Islam, Cambridge Medieval Textbooks (Cambridge, 2015).

Amit, Yaira, Hidden Polemics in Biblical Narrative, Biblical Interpretation Series 25 (Leiden, 2000).

Anheim, Étienne, L’humanisme est-il un polémisme ? À propos de Invectives de Pétrarque, in: Vincent Azoulay and Patrick Boucheron (eds.), Le mot qui tue: une histoire des violences intellectuelles de l'Antiquité à nos jours, Epoques (Seyssel, 2009) 116-129.

Ash, Mitchell G., Wissenschaft(en) und Öffentlichkeit(en) als Ressourcen füreinander, in: Sybilla Nikolow and Arne Schirrmacher (eds.), Wissenschaft und Öffentlichkeit als Ressourcen füreinander: Studien zur Wissenschaftsgeschichte im 20. Jahrhundert (Frankfurt/ Main, 2007) 349-362.

Ashcroft, Bill, Gareth Griffiths, Helen Tiffin, Post-Colonial Studies: The Key Concepts (second edition) (London, 2009).

Aurast, Anna, and Goetz, Hans-Werner (eds.), Die Wahrnehmung anderer Religionen im früheren Mittelalter: terminologische Probleme und methodische Ansätze, Hamburger Geisteswissenschaftliche Studien zu Religion und Gesellschaft 1 (Münster, 2012). 
Azoulay, Vincent and Boucheron, Patrick (eds.), Le mot qui tue: une histoire des violences intellectuelles de l'Antiquité à nos jours, Epoques (Seyssel, 2009).

Azoulay, Vincent and Boucheron, Patrick, Les violences intellectuelles, nouvel objet d'histoire, in: Azoulay, Vincent and Boucheron, Patrick (eds.), Le mot qui tue: une histoire des violences intellectuelles de l'Antiquité à nos jours, Epoques (Seyssel, 2009) 23-52.

Bale, Anthony Paul, The Jew in the Medieval Book: English Antisemitisms, 1350-150o, Cambridge Studies in Medieval Literature (Cambridge, 2006).

Barton, Carlin A., and Daniel Boyarin (eds.), Imagine No Religion: How Modern Abstractions Hide Ancient Realities (New York, 2016).

Baskind, James, Christian-Buddhist Polemics in Late Medieval/Early Modern Japan, Religion Compass 8/2 (2014) 37-48.

Baumann, Uwe, Becker, Arnold, and Laureys, Marc (eds.), Polemik im Dialog des RenaissanceHumanismus: Formen, Entwicklungen und Funktionen, Super alta perennis 19 (Göttingen, 2015).

Baumgarten, Elisheva, and Galinsky, Karl (eds.), Jews and Christians in Thirteenth-Century France, The New Middle Ages (New York, 2015).

Baumgarten, Elisheva, Mazo Karras, Ruth, and Mesler, Katelyn (eds.), Entangled Histories: Knowledge, Authority, and Jewish Culture in the Thirteenth Century, Jewish Culture and Contexts. (Philadelphia, 2017).

Bataillon, Louis Jacques, Une intervention maladroite de Pierre de Tarentaise en faveur des mendiants, in: Thomas Prügl and Marianne Schlosser (eds.), Kirchenbild und Spiritualität. Dominikanische Beiträge zur Ekklesiologie und zum kirchlichen Leben im Mittelalter. Festschrift für Ulrich Horst OP zum 75. Geburtstag (Paderborn, 2007) 143-177.

Bechmann, Ulrike, Prenner, Karl, and Renhart, Erich (eds.), Der Islam im kulturellen Gedächtnis des Abendlandes (Graz, 2014).

Beck, Hans-Georg, Kirche und theologische Literatur im byzantinischen Reich, 2 vols. (Munich, 1959).

Becker, Adam H., and Yoshiko Reed, Annette, The Ways That Never Parted:Jews and Christians in Late Antiquity and the Early Middle Ages (Tübingen, 2003).

Berend, Nora, At the Gate of Christendom: Jews, Muslims, and "Pagans" in Medieval Hungary, $c$. 1000-c. 1300, Cambridge Studies in Medieval Life and Thought (Cambridge, 2001).

Berger, David, Christian Heresy and Jewish Polemic in the Twelfth and Thirteenth Centuries, in: David Berger, Persecution, Polemic and Dialogue. Essays in Jewish-Christian Relations, Judaims and Jewish Life (Boston, 2010) 209-226.

Berger, David, Introduction to The Christian-Jewish Debate in the High Middle Ages, in: Berger, Persecution, Polemic and Dialogue, 75-109.

Berger, David, Persecution, Polemic, and Dialogue: Essays in Jewish-Christian Relations, Judaism and Jewish Life (Boston, 2010).

Berger, David, How, When, and to What Degree Was the Jewish-Christian Debate Transformed in the Twelfth and Thirteenth Centuries?, in: Elisheva Baumgarten and Judah D. Galinsky (eds.), Jews and Christians in Thirteenth-Century France (New York, 2015) 123-137.

Berger, David, Perlmann, Moshe and Daniel, Norman, Polemics, in: Lindsay Jones (ed.), Encyclopedia of Religion, Vol. 11 (Detroit, 2005) 7230-7244.

Biller, Peter, Words and the Medieval Notion of >Religion', Journal of Ecclesiastical History 36/3 (1985) 351-369.

Blumenkranz, Bernhard, Les auteurs Chrétiens latins du Moyen Âge sur les Juifs et le Judaïsme, Collection de la Revue des Études Juives (Paris, 2007). 
Bonfil, Robert, Irshai, Oded, Stroumsa, Guy G., and Talgam, Rina (eds.) Jews in Byzantium: Dialectics of Minority and Majority Cultures, Jerusalem Studies in Religion and Culture (Leiden, 2011).

Borgolte, Michael, and Schneidmüller, Bernd (eds.), Hybride Kulturen im mittelalterlichen Europa: Vorträge und Workshops einer internationalen Frühlingsschule, Europa im Mittelalter. Abhandlungen und Beiträge zur historischen Komparatistik 16 (Berlin, 2010).

Bouhaïk-Gironès, Marie, Debbagi Baranova, Tatiana, and Szczech, Nathalie (eds.), Usages et stratégies polémiques en Europe: (XIVe-premier XVIIe siècles) (Brussels, 2016).

Bouquet, Damien, and Nagy, Piroska, Sensible Moyen Âge: une histoire des émotions dans l'Occident médiéval, L'univers historique (Paris, 2015).

Bourdieu, Pierre, Genèse et structure du champ religieux, Revue française de sociologie 12/3 (1971) 295-334.

Boyarin, Daniel, Border Lines: The Partition of Judaeo-Christianity (Philadelphia, Pennsylvania, 2010).

Brandes, Wolfram, Schmieder, Felicitas, and Voss, Rebekka (eds.), Peoples of the Apocalypse: Eschatological Beliefs and Political Scenarios, Millenium-Studien zu Kultur und Geschichte des ersten Jahrtausends/Millennium Studies in the Culture and History of the First Millennium 63 (Berlin, 2016).

Brauner, Christina, and Steckel, Sita, Wie die Heiden - Wie die Papisten. Religiöse Polemik und Vergleiche vom Spätmittelalter bis zur Konfessionalisierung, in: Matthias Pohlig (ed.), Juden, Christen und Muslime im Zeitalter der Reformation, Schriften des Vereins für Reformationsgeschichte 220 (Gütersloh, 2019) (forthcoming).

Bremer, Kai, Religionsstreitigkeiten: Volkssprachliche Kontroversen zwischen altgläubigen und evangelischen Theologen im 16. Jahrhundert (Berlin, 2005).

Bremer, Kai, and Spoerhase, Carlos (eds.) Gelehrte Polemik. Intellektuelle Konfliktverschärfungen um 170o, Zeitsprünge. Forschungen zur Frühen Neuzeit 15 (Frankfurt/Main, 2011).

Bremer, Kai, and Spoerhase, Carlos (eds.), "Theologisch-polemisch-poetische Sachen «: Gelehrte Polemik im 18. Jahrhundert, Zeitsprünge. Forschungen zur Frühen Neuzeit 19 (Frankfurt am Main, 2015).

Bremer, Kai, and Spoerhase, Carlos, Rhetorische Rücksichtslosigkeit. Problemfelder der Erforschung gelehrter Polemik um 1700, in: Bremer and Spoerhase, Gelehrte Polemik, 111122.

Brentjes, Sonja, Medieval Portolan Charts as Documents of Shared Cultural Spaces, in: Rania Abdellatif, Yassir Benhima, Daniel König, and Elisabeth Ruchaud (eds.), Acteurs des transferts culturels en Méditerranée médiévale, Ateliers des DHI Paris 9 (München, 2012) 135-146.

Brentjes, Sonja, Fidora, Alexander, and Tischler, Matthias M., Towards a New Approach to Medieval Cross-Cultural Exchanges, Journal of Transcultural Medieval Studies 1/1 (2014) 9-50.

Bruschi, Caterina, Falsembiante-Inquisitor? Images and Stereotypes of Franciscan Inquisitors between Literature and Juridical Texts, in: Marco Veglia, Lorenzo Paolini, and Riccardo Parmeggiani (eds.), Il mondo errante: Dante fra letteratura, eresia e storia: atti del convegno internazionale di studio: Bertinoro, 13-16 Settembre 2010 (Spoleto, 2013) 99-136.

Bucossi, Alexandra, Dialogue and Anthologies of the Sacred Arsenal by Andronikos Kamateros: Sources, Arrangements, Purposes, in: P. van Deun and C. Macé (eds.), Encyclopedic Trends in Byzantium? Proceedings of the International Conference held in Leuven, 6-8 May 2009, Orientalia Lovaniensia Analecta 212 (Leuven, 2011) 269-286. 
Burman, Thomas E., Religious Polemic and the Intellectual History of the Mozarabs: C. 10501200 (Leiden, 1994).

Burrows, Daron L., The Stereotype of the Priest in the Old French Fabliaux: Anticlerical Satire and Lay Identity (Oxford, 2005).

Butler, Judith, Excitable Speech: A Politics of the Performative (New York, 1997).

Büttgen, Philippe, De Libera, Alain, Catach-Rosier, Irene, and Rashed, Marwan (eds.), Les Grecs, les Arabes et nous: enquête sur l'islamophobie savante (Paris, 2009).

Cailly, Marie, Les fabliaux - la satire et son public: l'oralité dans la poésie satirique et profane en France, XIIe-XIVe siècles (Cahors, 2007).

Cancik, Hubert, Apologetik/Polemik, in: Hubert Cancik (ed.), Handbuch Religionswissenschaftlicher Grundbegriffe, Vol. 2: Apokalyptik - Geschichte (Stuttgart, 1990) 29-37.

Carlebach, Elisheva, and Schacter, Jacob J. (eds.), New Perspectives on Jewish-Christian Relations. In Honor of David Berger, The Brill Reference Library of Judaism 33 (Leiden, 2012).

Cavarzere, Marco, A Comparative Method for Sixteenth-Century Polemicists: Cults, Devotions, and the Formation of Early Modern Religious Identities, Journal of Early Modern History 19/5 (2015) 385-407.

Chazan, Robert, From Anti-Judaism to Anti-Semitism: Ancient and Medieval Constructions of Jewish history (Cambridge, 2016).

Classen, Albrecht (ed.), Laughter in the Middle Ages and Early Modern Times: Epistemology of a Fundamental Human Behavior, its Meaning, and Consequences, Fundamentals of Medieval and Early Modern Culture 5 (New York, 2010).

Clement, Jennifer, Introduction: Rhetoric, Emotion and the Early Modern English Sermon, English Studies 98/7 (2017) 655-660.

Cluse, Christoph (ed.), Europas Juden im Mittelalter: Beiträge des internationalen Symposiums in Speyer vom 20.-25. Oktober 2002 (Trier, 2004).

Cohen, Jeremy, Towards a Functional Classification of Jewish anti-Christian Polemic in the High Middle Ages, in: Bernard Lewis und Friedrich Niewöhner (eds.), Religionsgespräche im Mittelalter, Wolfenbütteler Mittelalter-Studien 4 (Wiesbaden, 1992) 93-114.

Cohen, Jeremy, Living Letters of the Law. Ideas of the Jew in Medieval Christianity (Berkeley, 1999).

Cohen, Jeremy (ed.), The Postcolonial Middle Ages, The New Middle Ages (New York, 2000).

Cohen, Mark R. The Middle Ages, in: Abdelwahab Meddeb, Michael B Smith, Benjamin Stora and Jane Marie Todd (eds.), A History of Jewish-Muslim Relations from the Origins to the Present Day (Princeton, 2013) 28-163.

Coleman, Edward, Nasty Habits - Satire and the Medieval Monk, History Today 43/6 (1993) 36-42.

Colominas Aparicio, Mònica, The Religious Polemics of the Muslims of Late Medieval Christian Iberia. Identity and Religious Authority in Mudejar Islam, The Medieval and Early Modern Iberian World 64 (Leiden, 2018) forthcoming.

Conermann, Stephan (ed), Muslim-Jewish Relations in the Middle Islamic Period: Jews in the Ayyubid and Mamluk Sultanates (1171-1517), Mamluk Studies 16 (Göttingen, 2017).

Conklin Akbari, Suzanne, Idols in the East: European representations of Islam and the Orient, 1100-1450 (Ithaca, New York, 2009).

Connell, Charles W., Popular Opinion in the Middle Ages: Channeling Public Ideas and Attitudes, Fundamentals of Medieval and Early Modern Culture 18 (Berlin, 2016).

Corbellini, Sabrina (ed.), Cultures of Religious Reading in the Late Middle Ages: Instructing the Soul, Feeding the Spirit, and Awakening the Passion (Turnhout, 2013). 
Cuffel, Alexandra, Gendering Disgust in Medieval Religious Polemic (Notre Dame, Indiana, 2007).

Cuffel, Alexandra, The Matter of Others: Menstrual Blood and Uncontrolled Semen in Thirteenth-Century Kabbalist's Polemic Against Christians, >Bad Jews and Muslims, in: Katherine Allan Smith and Scott Wells (eds.), Negotiating Community and Difference in Medieval Europe: Gender, Power, Patronage and the Authority of Religion in Latin Christiandom, Studies in the History of Christian Tradition 142 (Leiden, 2009) 249-284.

Cuffel, Alexandra, Ibn Sahula's Meshal Ha-Qadmoni as Restorative Polemic, Journal of Medieval Iberian Studies 3/2 (2011) 165-186.

Cuffel, Alexandra, Between Epic Entertainment and Polemical Exegesis: Jesus as Antihero in Toledot Yeshu, in: Ryan Szpiech (ed.) Medieval Exegesis and Religious Difference: Commentary, Conflict, and Community in the Premodern Mediterranean, Bordering Religions (New York, 2015) 155-170.

Dahan, Gilbert. Les intellectuels chrétiens et les juifs au Moyen Âge, Patrimoines (Paris, 1990).

Dahan, Gilbert, The Christian Polemic Against the Jews in the Middle Ages (Notre Dame, Indiana, 1998).

Dascal, Marcelo, On the Uses of Argumentative Reason in Religious Polemics, in: Theo L. Hettema und Arie Van der Kooij (eds.), Religious Polemics in Context, Papers Presented to the Second International Conference of the Leiden Institute for the Study of Religions (LISOR), held at Leiden, 27-28 April 2000, Studies in Theology and Religion 11 (Assen, 2004) 3-20.

Daston, Lorraine, and Galison, Peter (eds.), Objectivity (New York, Massachusetts, 2007).

Dege-Müller, Sophia, Between Heretics and Jews: Inventing Jewish Identities in Ethiopia, Entangled Religions 6 (2018) 247-308.

De Jong, Mayke, Admonitio and Criticism of the Ruler at the Court of Louis the Pious, in: François Bougard, Régine Le Jan, and Rosamond McKitterick (eds.), La culture du haut Moyen Âge: Une question d'élites? Collection Haut Moyen Âge 7 (Turnhout, 2009) 315-138.

De Libera, Alain, Penser au Moyen Âge, Chemins de pensée (Paris, 1991).

Desmons, Eric, and Paveau, Marie-Anne (eds.), Outrages, insultes, blasphèmes et injures: violences du langage et polices $d u$ discours (Paris, 2008).

Destemberg, Antoine, L'espace public de la polémique: lecture croisée, in: Sère, Régimes de la polémicité, forthcoming.

Di Cesare, Michelina, The Pseudo-Historical Image of the Prophet Muhammad in Medieval Latin Literature: A Repertory, Studien zur Geschichte und Kultur des islamischen Orients 26 (Berlin, 2011).

Diamond, James A., Converts, Heretics, and Lepers: Maimonides and the Outsider (Notre Dame, Indiana, 2007).

Doležalová, Lucie, Passion and Passion: Intertextual Narratives from Late Medieval Bohemia between Typology, History and Parody, in: Marek Thue Kretschmer (ed.), La Typologie biblique comme forme de pensée dans l'historiographie médiévale (Turnhout, 2014) 245-265.

Donneaud, Henry, Histoire d'une histoire. M.-D. Chenu et La théologie comme science au XIIIe siècle, Mémoire Dominicaine. Histoire-Documents-Vie dominicaine 4 (1994) 139-175.

Douglas, Mary, Purity and Danger: An Analysis of Concepts of Pollution and Taboo, Collected Works 2 (London - New York, 2013).

Drews, Wolfram, and Scholl, Christian (eds.), Transkulturelle Verflechtungsprozesse in der Vormoderne, Das Mittelalter. Perspektiven mediävistischer Forschung, Beihefte 3 (Berlin, 2016). 
Duschinsky, Robbie, Weiss, Daniel H., and Schnall, Simone (eds.), Purity and Danger Now: New Perspectives (London, 2016).

Dykema, Peter A., and Oberman, Heiko A. (eds.), Anticlericalism in Late Medieval and Early Modern Europe, Studies in Medieval and Reformation Thought 51 (Leiden, 1993).

Elmer, Ian J., Pillars, Hypocrites and False Brothers. Paul's Polemic against Jerusalem in Galatians, in: Oda Wischmeyer and Lorenzo Scornaienchi (eds.), Polemik in der frühchristlichen Literatur. Texte und Kontexte, Beihefte zur Zeitschrift für die neutestamentliche Wissenschaft und die Kunde der älteren Kirche 170 (Berlin, 2011) 123-153.

Emmerson, Richard K., and Herzman, Ronald B., The Apocalyptic Age of Hypocrisy: Faus Semblant and Amant in the Roman de la Rose, Speculum 62/3 (1987) 612-634.

Epple, Angelika, Doing Comparisons - ein praxeologischer Zugang zur Geschichte der Globalisierung/en, in: Angelika Epple and Walter Erhart (eds.), Die Welt beobachten. Praktiken des Vergleichens (Frankfurt, 2015) 161-199.

Epstein, Marc Michael, Dreams of Subversion in Medieval Jewish Art and Literature. (Philadelphia, Pennsylvania, 1997).

Ess, Josef van, Der Eine und das Andere: Beobachtungen an islamischen häresiographischen Texten, Studien zur Geschichte und Kultur des islamischen Orients N. F. 23 (Berlin, 2011).

Fidora, Alexander, The Latin Talmud and Its Place in Medieval Anti-Jewish Polemic, in: Ulisse Cecini and Eulàlia Vernet (eds.), Studies on the Latin Talmud (Bellaterra, 2017) 13-21.

Fierro, Maribel (ed.), Orthodoxy and Heresy in Islam, Critical Concepts in Islam, 4 vols. (Abingdon, 2014).

Fierro, Maribel, and Tolan, John V. (eds.), The Legal Status of Dimmi-s in the Islamic West: Second, Eighth-Ninth, Fifteenth Centuries, Religion and Law in Medieval Christian and Muslim Societies 1 (Turnhout, 2013).

Flasch, Kurt, and Jeck, Udo Reinhold (eds.), Das Licht der Vernunft. Die Anfänge der Aufklärung im Mittelalter (München, 1997).

Foucault, Michel, Polemics, Politics and Problematizations, Paul Rabinow (ed.), Essential Works of Foucault 1954-1984, Vol. 1: Ethics: Subjectivity and Truth, translated by Robert Hurley (London, 2000) 111-119.

Frakes, Jerold C. (ed.), Contextualizing the Muslim Other in Medieval Christian Discourse, The New Middle Ages (New York, 2011).

Frank, Daniel, The Jews of Medieval Islam: Community, Society, and Identity (Leiden, 1995).

Fraser, Nancy, Rethinking the Public Sphere: A Contribution to the Critique of Actually Existing Democracy, Social Text 25-26 (1990) 56-80.

Frassetto, Michael (ed.), Heresy and the Persecuting Society in the Middle Ages: Essays on the Work of R. I. Moore, Studies in the History of Christian Traditions 129 (Leiden, 2006).

Freidenreich, David M., and Goldstein, Miriam (eds.), Beyond Religious Borders: Interaction and Intellectual Exchange in the Medieval Islamic World (Philadelphia, 2011).

Freidenreich, David, Foreigners and Their Food. Constructing Otherness in Jewish, Christian, and Islamic Law (Berkeley, 2014).

Freudenberg, Bele, Irarum nutrix. Emotionen und Ehrverletzungen bei William of Newburgh, Richard of Devizes und Walter Map (Bochum, 2014).

Freudenthal, Gad, Arabic into Hebrew: The Emergence of the Translation Movement in Twelfth-Century Provence and Jewish-Christian Polemic, in: Freidenreich and Goldstein, Beyond Religious Borders, 124-143.

Friedmann, Yohanan, Tolerance and Coercion in Islam: Interfaith Relations in the Muslim Tradition (Cambridge, 2003). 
Füssel, Marian, Die Gelehrtenrepublik im Kriegszustand. Zur bellizitären Metaphorik von gelehrten Streitkulturen der Frühen Neuzeit, in: Kai Bremer und Carlos Spoerhase (eds.), Gelehrte Polemik. Intellektuelle Konfliktverschärfungen um 1700, Zeitsprünge. Forschungen zur Frühen Neuzeit 15 (Frankfurt am Main, 2011) 158-175.

Funkenstein, Amos, Basic Types of Christian Anti-Jewish Polemics in the Later Middle Ages, Viator 2 (1971) 373-382.

Gálik, Marián, and Slobodník, Martin (eds), Eastern Christianity, Judaism and Islam between the Death of Muhammad and Tamerlane (632-1405) (Bratislava, 2011).

Garcia, Michel, and Beaumatin, Eric (eds.), L'invective au Moyen Âge: France, Espagne, Italie, Actes du colloque "L'invective au Moyen Âge", Paris, 4-6 février 1993 (Paris, 1995).

Garloff, Mona, Irenik, Gelehrsamkeit und Politik: Jean Hotman und der europäische Religionskonflikt um 1600, Schriften zur politischen Kommunikation 18 (Göttingen, 2014).

Gaunt, Simon, Can the Middle Ages Be Postcolonial?, Comparative Literature 61/2 (2009) 160-176.

Gay, Jean-Pascal, Lettres de controverse. Religion, publication et espace public en France au xviie siècle, Annales. Histoire, Sciences Sociales, 68/1 (2013) 7-41.

Geltner, Guy, The Making of Medieval Antifraternalism: Polemic, Violence, Deviance, and Remembrance (Oxford, 2012).

Gierl, Martin, Pietismus und Aufklärung. Theologische Polemik und die Kommunikationsreform der Wissenschaft am Ende des 17. Jahrhunderts, Veröffentlichungen des Max-Planck-Instituts für Geschichte 129 (Göttingen, 1997).

Gieryn, Thomas F. Boundary-Work and the Demarcation of Science from Non-Science: Strains and Interests in Professional Ideologies of Scientists, American Sociological Review 48/6 (1983) 781-795.

Giraud, Cédric, Discours magistral, parole d'autorité et violence cachée dans les sentences d'Anselme de Laon († 1117), in: Azoulay and Boucheron, Le mot qui tue, 263-274.

Glei, Reinhold F., and Reichmuth, Stefan, Religion between Last Judgement, Law and Faith. Koranic din and its rendering in the Latin Translations of the Koran, Religion 42/2 (2012) 247-271.

Goertz, Hans-Jürgen, Antiklerikalismus und Reformation. Sozialgeschichtliche Untersuchungen (Göttingen, 1995).

Goetz, Hans-Werner, Die Wahrnehmung anderer Religionen und christlich-abendländisches Selbstverständnis im frühen und hohen Mittelalter (5.-12. Jahrhundert), 2 vols. (Berlin, 2013).

Gorisse, Marie-Helene, The Taste of the Mango: A Jaina-Buddhist Controversy on Evidence, International Journal of Jaina Studies 11/3 (2015) 1-19.

Groebner, Valentin, Defaced: The Visual Culture of Violence in the Late Middle Ages (New York, 2004).

Grundmann, Herbert, Ketzerverhöre des Spätmittelalters als quellenkritisches Problem, in: Herbert Grundmann, Ausgewählte Aufsätze, Band 1: Religiöse Bewegungen, Schriften der Monumenta Germaniae Historica 25 ( Stuttgart, 1976) 360-416.

Grundmann, Herbert, Religious Movements in the Middle Ages: The Historical Links between Heresy, the Mendicant Orders, and the Women's Religious Movement in the Twelfth and Thirteenth Century, with the Historical Foundations of German Mysticism (Notre Dame, Indiana, 1995).

Habermas, Jürgen, Strukturwandel der Öffentlichkeit. Untersuchungen zu einer Kategorie der bürgerlichen Gesellschaft. Mit einem Vorwort zur Neuauflage von 1990, Suhrkamp Taschenbuch Wissenschaft 891 (Frankfurt am Main, 1990). 
Hames, Harvey J., Reconstructing Thirteenth-Century Jewish-Christian Polemic: From Paris 1240 to Barcelona 1263 and Back Again, in: Szpiech, Medieval Exegesis and Religious Difference, $115-127$.

Hamm, Berndt, Was ist Frömmigkeitstheologie? Überlegungen zum 14. bis 16. Jahrhundert, in: Reinhold Friedrich and Wolfgang Simon (eds.), Religiosität im späten Mittelalter: Spannungspole, Neuaufbrüche, Normierungen, Spätmittelalter, Humanismus, Reformation 54 (Tübingen, 2011) 115-153.

Hasselhoff, Görge K., Huldrych Zwinglis Verständnis von religio (’Religion'), Zeitschrift für Religions- und Geistesgeschichte 67/2 (2015) 120-141.

Hasselhoff, Görge K., and Stünkel, Knut Martin (eds.), Transcending Words: The Language of Religious Contact between Buddhists, Christians, Jews, and Muslims in Premodern Times (Bochum, 2015).

Helmrath, Johannes, Streitkultur. Die "Invektive« bei den italienischen Humanisten, in: Marc Laureys and Roswitha Simon (eds.), Die Kunst des Streitens. Inszenierung, Formen und Funktionen öffentlichen Streits in historischer Perspektive (Göttingen, 2010) 259-294.

Herbers, Klaus, and Jaspert, Nikolas (eds.), Integration, Segregation, Vertreibung. Religiöse Minderheiten und Randgruppen auf der Iberischen Halbinsel (7. bis 17. Jahrhundert), Geschichte und Kultur der Iberischen Welt 8 (Münster, 2011).

Henderson, John B, The Construction of Orthodoxy and Heresy: Neo-Confucian, Islamic, Jewish, and Early Christian Patterns (Albany, New York, 1998).

Hess, Cordelia, and Adams, Jonathan (eds.), Fear and Loathing in the North: Jews and Muslims in Medieval Scandinavia and the Baltic Region (Berlin, 2015).

Hettema, Theo L., and Arie van der Kooij (eds.), Religious Polemics in Context: Papers Presented to the Second International Conference of the Leiden Institute for the Study of Religions (Lisor) held at Leiden, 27-28 April, 2000, Studies in Theology and Religion 11 (Assen, 2004).

Hettema, Theo L., and Van der Kooij, Arie, Introduction, in: Hettema and Van der Kooij, Religious Polemics in Context, xi-xxv.

Hirschi, Caspar, Piraten der Gelehrtenrepublik. Die Norm des sachlichen Streits und ihre polemische Funktion, in: Bremer and Spoerhase, Gelehrte Polemik, 176-213.

Hobbins, Daniel, Authorship and Publicity Before Print: Jean Gerson and the Transformation of Late Medieval Learning, Middle Ages Series (Philadelphia, Pennsylvania, 2011).

Höckelmann, Michael, Antiklerikalismus und Exklusionsrhetorik in der Tang-Zeit. Religionspolitik im Denken Li Deyus, Bochumer Jahrbuch zur Ostasienforschung 34 (2010) 181213.

Höfert, Almut, Europa und der Nahe Osten. Der transkulturelle Vergleich in der Vormoderne und die Meistererzählungen über den Islam, Historische Zeitschrift 287/3 (2008) 561-597.

Höfert, Almut, Den Feind beschreiben: "Türkengefahr« und europäisches Wissen über das Osmanische Reich 1450-1600 (Campus Historische Studien 35 (Frankfurt/Main, 2003).

Höfert, Almut, Alteritätsdiskurse. Analyseparameter historischer Antagonismusnarrative und ihre historiographischen Folgen, in: Gabriele Haug-Moritz and Ludolf Pelizaeus (eds.), Repräsentationen der islamischen Welt im Europa der Frühen Neuzeit (Münster, 2010) 21-40.

Hohlstein, Michael, Soziale Ausgrenzung im Medium der Predigt. Der franziskanische Antijudaismus im spätmittelalterlichen Italien, Norm und Struktur. Studien zum sozialen Wandel im Mittelalter und Früher Neuzeit 35 (Cologne, 2012).

Holzem, Andreas (ed.), Krieg und Christentum. Religiöse Gewalttheorien in der Kriegserfahrung des Westens, Krieg in der Geschichte 50 (Paderborn, 2009). 
Hovden, Eirik, Lutter, Christina, and Pohl, Walter (eds.), Meanings of Community across Medieval Eurasia: Comparative Approaches, Brill's Series on the Early Middle Ages 25 (Leiden, 2016).

Hoyland, Robert G. (ed.), Muslims and Others in Early Islamic Society, The Formation of the Classical Islamic World 18 (Burlington, Vermont, 2004).

Huot, Sylvia, The Romance of the Rose and Its Medieval Readers: Interpretation, Reception, Manuscript Transmission, Cambridge Studies in Medieval Literature 16 (Cambridge, 1993).

Hureau, Sylvie, L'apparition de thèmes anticléricaux dans la polémique anti-bouddhique médiévale, Extrême-Orient, Extrême-Occident 24 (2002) 17-29.

Iogna-Prat, Dominique, Order and Exclusion: Cluny and Christendom Face Heresy, Judaism, and Islam (1000-1150), Conjunctions of Religion and Power in the Medieval Past (Ithaca, New York, 2002).

Iricinschi, Eduard, and Zellentin, Holger M. (eds.) Heresy and Identity in Late Antiquity, Texts and Studies in Ancient Judaism/Texte und Studien zum antiken Judentum 119 (Tübingen, 2008).

Iyengar, Shanto, and Westwood, Sean Jeremy, Fear and Loathing Across Party Lines: New Evidence on Group Polarization, American Journal of Political Science 59/3 (2015) 690-707.

Jaspert, Nikolas, Communicating Vessels: Ecclesiastic Centralisation, Religious Diversity and Knowledge in Medieval Latin Europe, The Medieval History Journal 16/2 (2013) 389-424.

Jaspert, Nikolas, Politische Öffentlichkeit im Spätmittelalter: Zusammenfassung, in: Martin Kintzinger and Bernd Schneidmüller (eds.), Politische Öffentlichkeit im Spätmittelalter, Vorträge und Forschungen 75 (Ostfildern, 2011) 433-449.

Johnson, Hannah, and Blurton, Heather, Virtual Jews and Figural Criticism: Recent Scholarship on the Idea of the Jew in Western Culture, Philological Quarterly 92/1 (2013) 115-130.

Keil, Martha, Orte jüdischer Öffentlichkeit: Judenviertel, Synagoge, Friedhof, in: Eveline Brugger und Birgit Wiedl (eds.), Ein Thema - zwei Perspektiven: Juden und Christen in Mittelalter und Frühneuzeit (Innsbruck, 2007) 170-188.

Kendrick, Laura, Medieval Satire, in: Ruben Quintero (ed.), A Companion to Satire: Ancient and Modern (Oxford, 2007) 52-68.

Kerby-Fulton, Kathryn, Hayton, Magda, and Olsen, Kenna, Pseudo-Hildegardian Prophecy and Antimendicant Propaganda in Late Medieval England: An Edition of the Most Popular Insular Text of 'Insurgent Gentes‘, in: Nigel John Morgan (ed.), Prophecy, Apocalypse and the Day of Doom: Proceedings of the 2000 Harlaxton Symposium, Harlaxton Medieval Studies (Donington, 2004) 160-194.

Kessler, Herbert L., and Nirenberg, David (eds.), Judaism and Christian Art: Aesthetic Anxieties from the Catacombs to Colonialism (Philadelphia, Pennsylvania, 2012).

Kienzle, Beverly Mayne, Preaching as Touchstone of Orthodoxy and Dissidence in the Middle Ages, Medieval Sermon Studies 43 (1999) 19-54.

Kim, Dorothy, Reframing Race and Jewish/Christian Relations in the Middle Ages, Transversal 13/ 1 (2015) 52-64.

Kindermann, Udo, Satyra: Die Theorie der Satire im Mittellateinischen: Vorstudie zu einer Gattungsgeschichte, Erlanger Beiträge zur Sprach- und Kunstwissenschaft 58 (Nürnberg, 1978).

Knappe, Gabriele, Flyting und die Rhetorik des verbalen Konflikts in der angelsächsischen Literatur, in: Oliver Auge, Felix Biermann, Matthias Müller, Dirk Schultze (eds.), Bereit zum Konflikt. Strategien und Medien der Konflikterzeugung (Stuttgart, 2008) 31-46. 
Koch, Bettina, Patterns Legitimizing Political Violence in Transcultural Perspectives: Islamic and Christian Traditions and Legacies, Judaism, Christianity, and Islam - Tension, Transmission, Transformation 1 (Boston, 2015).

König, Daniel, Ausstrahlung - transkulturelle Datenmigration - Dokumentation. Arabischislamische Gelehrte und die Herausforderungen der Dokumentation Lateineuropas am Beispiel des Papsttums und des ostfränkisch-deutschen Reiches, in: Michael Borgolte and Matthias M. Tischler (eds.), Transkulturelle Verflechtungen im mittelalterlichen Jahrtausend. Europa, Ostasien, Afrika (Darmstadt, 2012) 207-240.

König, Daniel, Arabic-Islamic Views of the Latin West: Tracing the Emergence of Medieval Europe (Oxford, 2015).

Kohn, Livia, Laughing at the Tao: Debates among Buddhists and Taoists in Medieval China (Princeton, 1995).

Krech, Volkhard, and Schwartz, Yossef (eds.), Religious Apologetics - Philosophical Argumentation, Religion in Philosophy and Theology 10 (Tübingen, 2004).

Krech, Volkhard, and Steinicke, Marion (eds.), Dynamics in the History of Religions Between Asia and Europe: Encounters, Notions, and Comparative Perspectives. Dynamics in the History of Religions 1 (Leiden, 2012).

Kolbaba, Tia M., The Byzantine Lists: Errors of the Latins, Illinois Medieval Studies (Chicago, 2000).

Lange, Christian, and Fierro, Maribel (eds), Public Violence in Islamic Societies. Power, Discipline and the Construction of the Public Sphere, 7th-19th Centuries CE (Edinburgh, 2009).

L'anticléricalisme en France méridionale (fin XIIe-début XIVe siècle), Cahiers de Fanjeaux 38 (Toulouse, 2003).

Lakoff, George, and Wehling, Elisabeth, Your Brain's Politics: How the Science of Mind Explains the Political Divide, Societas : Essays in Political and Cultural Criticism (Exeter, 2016).

Lambert, Malcolm D., Medieval Heresy: Popular Movements from the Gregorian Reform to the Reformation (Oxford, 2002).

Lasker, Daniel J., Jewish Philosophical Polemics against Christianity in the Middle Ages (New York, 1977).

Lasker, Daniel J., The Impact of Interreligious Polemic on Medieval Philosophy, in: David M. Freidenreich and Miriam Goldstein (eds.), Beyond Religious Borders: Interaction and Intellectual Exchange in the Medieval Islamic World (Philadelphia, Pennsylvania, 2011) 115-123.

Lau, Richard R., Andersen, David J., Ditonto, Tessa M., Kleinberg, Mona S., and Redlawsk, David P., Effect of Media Environment Diversity and Advertising Tone on Information Search, Selective Exposure, and Affective Polarization, Political Behavior 39/1 (2017) 231255.

Laursen, John Christian, Nederman, Cary J. and Hunter, Ian (eds.), Heresy in Transition: Transforming Ideas of Heresy in Medieval and Early Modern Europe (Catholic Christendom, 1300-1700) (Aldershot, 2005).

Lazarus-Yafeh, Hava, Intertwined Worlds: Medieval Islam and Bible Criticism (Princeton, 1992). Lembke, Astrid (ed.), Biblical Creatures - The Animal as an Object of Interpretation in Pre-Modern Abrahamic Hermeneutic Traditions, Special issue of Interfaces: A Journal of Medieval European Literature (2018) forthcoming.

Levine, Robert, Why Praise Jews? History and Satire in the Middle Ages, Journal of Medieval History 12 (1986) 291-296.

Lewis, Bernard and Niewöhner, Friedrich (eds.), Religionsgespräche im Mittelalter, Wolfenbütteler Mittelalter-Studien 4 (Wiesbaden, 1992). 
Limor, Ora, Die Disputationen zu Ceuta (1179) und Mallorca (1286). Zwei antijüdische Schriften aus dem mittelalterlichen Genua, MGH Schriften zur Geistesgeschichte des Mittelalters 15 (Hannover, 1994).

Limor, Ora, Polemical Varietes: Religious Disputations in Thirteenth Century Spain, Iberia Judaica 2 (2010) 55-79.

Limor, Ora and Stroumsa, Guy G. (eds.), Contra Iudaeos: Ancient and Medieval Polemics between Christians and Jews, Texts and Studies in Medieval and Early Modern Judaism 10 (Tübingen, 1996).

Liu, Kwang-Ching and Shek, Richard (eds.), Heterodoxy in Late Imperial China (Honolulu, 2004).

Lourdaux, Willem, and Verhelst, Daniel (eds.), The Concept of Heresy in the Middle Ages (11th13th c.): Proceedings of the International Conference Louvain, May 13-16, 1973 (Leuven, 1976).

Love, Nancy S., Foucault and Habermas on Discourse and Democracy, Polity 22/2 (1989) 269-293.

Lubenow, Jorge Adriano, Public Sphere and Deliberative Democracy in Jürgen Habermas: Theoretical Model and Critical Discourses, American Journal of Sociological Research 2/4 (2012) 58-71.

Lutz-Bachmann, Matthias and Fidora, Alexander (eds.), Juden, Christen und Muslime. Religionsdialoge im Mittelalter (Darmstadt, 2004).

Lutz-Bachmann, Matthias, Rationalität und Religion. Der Beitrag des Thomas von Aquin zu eienr rationalen Grundlegung des Religionsdialogs in der Summa contra gentiles, in: Lutz-Bachmann and Fidora, Juden, Christen und Muslime, 96-118.

Malek, Roman, and Hofrichter, Peter (eds.), Jingjiao: The Church of the East in China and Central Asia, Collectanea Serica (Sankt Augustin, 2006).

Mann, Jill, Chaucer and Medieval Estates Satire: The Literature of Social Classes and the General Prologue to the Canterbury Tales (Cambridge, 1973).

Mann, Jill, Satiric Subject and Satiric Object in Goliardic Literature, Mittellateinisches Jahrbuch 15 (1980) 63-86.

Marcus, George E., Neuman, W. Russell, and MacKuen, Michael, Affective Intelligence and Political Judgment (Chicago, 2000).

Marcus, Ivan, A Jewish-Christian Symbiosis: The Culture of Early Ashkenaz, in: David Biale (ed.), Cultures of the Jews: A New History (New York, 2002) 449-518.

Marmursztejn, Elsa, L'autorité des maîtres: Scolastique, normes et société au XIIIe siècle (Paris, 2007).

Marx, Michael, Pahlitzsch, Johannes, and Weltecke, Dorothea, Östliches Christentum in Geschichte und Gegenwart - Perspektiven und Hindernisse der Forschung, Der Islam. Zeitschrift für Geschichte und Kultur des islamischen Orients 88 (2011) 1-10.

Matthes, Jörg, Framing, Konzepte. Ansätze der Medien- und Kommunikationswissenschaft 10 (Baden-Baden, 2014).

McGuire, Brian Patrick, Anti-Clerical Invective and the Growth of Clerical Satire, 1075-1400, in: Olle Ferm and Bridget Morris (eds.), Master Golyas and Sweden: The Transformation of a Clerical Satire, Sällskapet Runica et Mediaevalia. Scripta Minora 2 (Stockholm, 1997) 45-98.

Melve, Leidulf, Inventing the Public Sphere: The Public Debate During the Investiture Contest (c. 1030-1122), Brill's Studies in Intellectual History 154, 2 vols. (Leiden, 2007). 
Mercier, Franck, and Rosé, Isabelle (eds.), Aux marges de l'hérésie. Inventions, formes et usages polémiques de l'accusation d'hérésie au Moyen Âge, Histoire (Rennes, 2017).

Mews, Constant J., Communautés de savoirs. Écoles et collèges à Paris au XIIIe siècle, Revue de Synthèse 129/6 (2008) 485-507.

Miller, Maureen C. and Wheatley, Edward (eds.), Emotions, Communities, and Difference in Medieval Europe Essays in Honor of Barbara H. Rosenwein (London, 2017).

Miller, Timothy S. and Nesbitt, John W., Walking Corpses: Leprosy in Byzantium and the Medieval West (Ithaca, New York, 2014).

Monagle, Clare, Orthodoxy and Controversy in Twelfth-Century Religious Discourse. Peter Lombard's Sentences and the Development of Theology, Europa Sacra 8 (Turnhout, 2013).

Moore, Robert I., The Formation of a Persecuting Society: Authority and Deviance in Western Europe, 950-1250 (second edition) (Oxford, 2007).

Mulsow, Martin and Rexroth, Frank (eds.), Was als wissenschaftlich gelten darf: Praktiken der Grenzziehung in Gelehrtenmilieus der Vormoderne, Campus Historische Studien 70 (Frankfurt am Main, 2014).

Murphy, Kathryn and Traninger, Anita (eds.), The Emergence of Impartiality, Intersections: Interdisciplinary Studies in Early Modern Culture 31 (Leiden, 2014).

Nagy, Piroska and Boquet, Damien (eds.), Le sujet des émotions au Moyen Âge, Bibliothèque historique et littéraire (Paris, 2008).

Neumann, Uwe, Invektive, in: Gerd Ueding (ed.), Historisches Wörterbuch der Rhetorik Vol. 4: $H u-K$ (Tübingen, 1994) 549-561.

Niesner, Manuela, Wer mit juden well disputiren: Deutschsprachige Adversus-Judaeos-Literatur des 14. Jahrhunderts, Münchener Texte und Untersuchungen zur deutschen Literatur des Mittelalters 128 (Tübingen, 2005).

Nirenberg, David, Communities of Violence: Persecution of Minorities in the Middle Ages (Princeton, 1998).

Nirenberg, David, Anti-Judaism: The History of a Way of Thinking (New York, 2013).

Nirenberg, David, Neighboring Faiths: Christianity, Islam, and Judaism in the Middle Ages and Today (Chicago, 2014).

Nongbri, Brent, Before Religion: A History of a Modern Concept (New Haven, Connecticut, 2015).

Novikoff, Alex J., The Medieval Culture of Disputation: Pedagogy, Practice, and Performance, The Middle Ages series (Philadelphia, 2013).

Opelt, Ilona, Die lateinischen Schimpfwörter und verwandte sprachliche Erscheinungen. Eine Typologie, Bibliothek der klassischen Altertumswissenschaften N. F. 2 (Heidelberg, 1965).

Opelt, Ilona, Die Polemik in der christlichen lateinischen Literatur von Tertullian bis Augustin, Bibliothek der klassischen Altertumswissenschaften, N. F. 63 (Heidelberg, 1980).

Palumbo, Antonello, From Constantine the Great to Emperor Wu of the Liang: The Rhetoric of Imperial Conversion and the Divisive Emergence of Religious Identities in Late Antique Eurasia, in: Arietta Papaconstantinou, Neil McLynn and Daniel Louis Schwartz (eds.), Conversion in Late Antiquity: Christianity, Islam, and Beyond (second edition) (Abingdon, 2016) 95-122.

Pearsall, Derek, Medieval Monks and Friars: Differing Literary Perceptions, in: Robert F. Yeager, Toshiyuki Takamiya, und Terry Jones (eds.), The Medieval Python: The Purposive and Provocative Work of Terry Jones, The New Middle Ages (New York, 2012) 59-73.

Pietsch, Andreas N., Isaac La Peyrère: Bibelkritik, Philosemitismus und Patronage in der Gelehrtenrepublik des 17. Jahrhunderts, Frühe Neuzeit 163 (Berlin, 2012). 
Pietsch, Andreas N., Die junge Republik und ihre Konfession. Wahrheits- und Interessenkonflikte auf der Synode von Dordrecht (1618/19), in: Christoph Dartmann, Andreas Nikolaus Pietsch and Sita Steckel (eds.), Ecclesia disputans. Die Konfliktpraxis vormoderner Synoden zwischen Religion und Politik, Historische Zeitschrift Beihefte N. F. 67 (Berlin, 2015) 253-282.

Pietsch, Andreas N., and Steckel, Sita, New Religious Movements before Modernity? Observations from a Historical Perspective, Nova Religio: The Journal of Alternative and Ermergent Religions 22/1 (2018) forthcoming.

Piron, Sylvain, Écrire en aveugle. Jean de Roquetaillade ou la dissidence par l'obéissance, in: Gian Luca Potestà (ed.), Autorität und Wahrheit. Kirchliche Vorstellungen, Normen und Verfahren (13.-15. Jahrhundert), Schriften des Historischen Kollegs. Kolloquien 84 (München, 2012) 91-112.

Plamper, Jan, The History of Emotions: An Introduction (Oxford, 2015).

Pogossian, Zara, The Conceptual Frontier: The Armenian Church and its Relations with the Holy See (XI-XIIIth Centuries), in: Outi Merisalo, Frontiers in the Middle Ages (Louvain-laNeuve, 2006), 259-290.

Pogossian, Zaroui, Jews in Armenian Apocalyptic Traditions of the 12th century: A Fictional Community or New Encounters?, in: Wolfram Brandes, Felicitas Schmieder and Rebekka Voss (eds.), Peoples of the Apocalypse: Eschatological Beliefs and Political Scenarios, Millennium-Studien/Millennium studies 63 (Berlin, 2016) 147-192.

Przybilski, Martin, Zwei Beispiele antichristlicher Polemik in Spätantike und Mittelalter (תודלות ןשי tol'dot jeshu) und (ווחצנ ןשי nizzachon jaschan), in: Eveline Brugger and Birgit Wiedl (eds.), Ein Thema - zwei Perspektiven: Juden und Christen in Mittelalter und Frühneuzeit (Innsbruck, 2007) 253-268.

Ragacs, Ursula, "Mit Zaum und Zügel muss man ihr Ungestüm bändigen " Ps. 32, 9: Ein Beitrag zur christlichen Hebraistik und antijüdischen Polemik im Mittelalter, Judentum und Umwelt 65 (Frankfurt/Main, 1997).

Ragacs, Ursula, Reconstructing Medieval Jewish-Christian Disputations, in: Szpiech, Medieval Exegesis and Religious Difference, 101-114.

Resnick, Irven M., Good Dog/Bad Dog: Dogs in Medieval Religious Polecmics, Enarratio 18 (2013) 70-97.

Richardson, Kristina, Blue and Green Eyes in the Islamicate Middle Ages, Annales Islamologiques 48/1 (2014) 13-30.

Rigo, Antonio and Ermilov, Pavel (eds.), Orthodoxy and Heresy in Byzantium: The Definition and the Notion of Orthodoxy and Some Other Dtudies on the Heresies and the Non-Christian Religions, Quaderni di Néa Rhóme 4 (Rome, 2010).

Robinson, Ian S., Authority and Resistance in the Investiture Contest: The Polemical Literature of the Late Eleventh Century (New York, 1978).

Röcke, Werner and Velten, Hans Rudolf (eds.), Lachgemeinschaften. Kulturelle Inszenierungen und soziale Wirkungen von Gelächter im Spätmittelalter und in der Frühen Neuzeit, Trends in Medieval Philology 4 (Berlin, 2005).

Rose, E. M., The Murder of William of Norwich: The Origins of the Blood Libel in Medieval Europe (Oxford, 2015).

Rosenwein, Barbara H., Generations of Feeling: A History of Emotions, 600-170o (Cambridge, 2016).

Ruani, Flavia (ed.), Les controverses religieuses en syriaque, Etudes syriaques 13 (Paris, 2016). 
Rubin, Miri, Gentile Tales: The Narrative Assault on Late Medieval Jews (Philadelphia, Pennsylvania, 2004).

Rüegg, Walter (ed.), Universities in the Nineteenth and Early Twentieth Centuries (180o-1945), A history of the university in Europe 3 (Cambridge, 2004).

Rustow, Marina, Karaites Real and Imagined: Three Cases of Jewish Heresy, Past \& Present, 197 (2007) 35-74.

Rustow, Marina, Heresy and the Politics of Community: The Jews of the Fatimid Caliphate (Ithaca, New York, 2008).

Sackville, Lucy J., Heresy and Heretics in the Thirteenth Century: The Textual Representations (York, 2011).

Said, Edward W., Orientalism (New York, 1978).

Samir, Samir Halil and Nielsen, Jørgen S. (eds.), Christian Arabic Apologetics During the Abbasid Period (750-1258), Studies in the History of Religions 63 (Leiden, 1994).

Sauer, Birgit, `Bringing emotions back in`. Gefühle als Regierungstechnik: Geschlechterund demokratietheoretische Überlegungen, in: Claudia Jarzebowski and Anne Kwaschik (eds.), Performing Emotions: Interdisziplinäre Perspektiven auf das Verhältnis von Politik und Emotion in der Frühen Neuzeit und in der Moderne (Göttingen, 2013) 241-258.

Scase, Wendy, Piers Plowman and the New Anticlericalism, Cambridge Studies in Medieval Literature 4 (Cambridge, 1989).

Scharff, Thomas, Lachen über Ketzer. Religiöse Devianz und Gelächter im Hochmittelalter, in: Werner Röcke and Hans Rudolf Velten (eds.), Lachgemeinschaften: Kulturelle Inszenierungen und soziale Wirkungen von Gelächter im Mittelalter und in der frühen Neuzeit, Trends in Medieval Philology 4 (Berlin, 2005) 17-31.

Scheuer, Hans Jürgen and Veder, Ulrike (eds.), Tier im Text. Exemplarität und Allegorizität literarischer Lebewesen, Publikationen zur Zeitschrift für Germanistik N. F. 29 (Berne, 2015).

Schlögl, Rudolf, Politik beobachten. Öffentlichkeit und Medien in der Frühen Neuzeit, Zeitschrift für historische Forschung 35 (2008) 581-616.

Schmieder, Felicitas, Prophetische Propaganda in der Politik des 14. Jahrhunderts: Johannes von Rupescissa, in: Wolfram Brandes and Felicitas Schmieder (eds.), Endzeiten. Eschatologie in den monotheistischen Weltreligionen, Millenium-Studien zu Kultur und Geschichte des ersten Jahrtausends/Millennium Studies in the Culture and History of the First Millennium 16 (Berlin, 2008) 249-260.

Scholl, Christian, Materielle Hinterlassenschaften als Zeugen christlich-jüdischer Verflechtungen im mittelalterlichen Reich. Eine Skizze, in: Drews and Scholl, Transkulturelle Verflechtungsprozesse in der Vormoderne, 141-155.

Schrage, Eva-Maria, Von Ketzern und Terroristen? Zum analytischen Nutzen eines interdisziplinären Feindbildbegriffs, in: Harutyun Harutyunyan, Alfons Fürst, Eva-Maria Schrage and Verena Voigt (eds.), Von Ketzern und Terroristen: Interdisziplinäre Studien zur Konstruktion und Rezeption von Feindbildern (Münster, 2012) 217-238.

Schüppert, Helga, Kirchenkritik in der lateinischen Lyrik des 12. und 13. Jahrhunderts, Medium Aevum. Philologische Studien 23 (München, 1972).

Scribner, Robert W., Popular Culture and Popular Movements in Reformation Germany (London, 1987).

Scribner, Robert W., For the Sake of Simple Folk: Popular Propaganda for the German Reformation (Oxford, 1994).

Sère, Bénédicte, Thomas d'Aquin contre Siger de Brabant, 1270 : Chronique d'une dispute, in: Azoulay and Boucheron, Le mot qui tue, 99-115. 
Sère, Bénédicte, Les débats d'opinion à l'heure du Grand Schisme. Ecclésiologie et politique, Ecclesia militans 6 (Turnhout, 2016).

Sère, Bénédicte, Introduction, in: Bénédicte Sère (ed.), Les régimes de polémicité (Rennes, 2018) forthcoming.

Sère, Bénédicte (ed.), Les régimes de polémicité au Moyen Âge (Rennes, 2018) forthcoming.

Shachar, Isaiah, The Judensau: A Medieval Anti-Jewish Motif and its History, Warburg Institute Surveys 5 (London, 1974).

Shaked, Shaul, Dualism in Transformation: Varieties of Religion in Sasanian Iran, Jordan Lectures in Comparative Religion 16 (London, 1994).

Shalev-Eyni, Sarit, Martyrdom and Sexuality: The Case of an Eleventh-Century Piyyut for Hannukah and Its Visual Interpretation in the Fifteenth Century, in: Yisrael Yakov Yuval, and Ram Ben-Shalom (eds.), Conflict and Religious Conversation in Latin Christendom: Studies in Honour of Ora Limor, Cultural Encounters in Late Antiquity and the Middle Ages 17 (Turnhout, 2014) 133-166.

Shatzmiller, Joseph, Cultural Exchange: Jews, Christians, and Art in the Medieval Marketplace (Princeton, New Jersey, 2013).

Signori, Gabriela, Frauen, Kinder, Greise und Tyrannen. Geschlecht und Krieg in der Bilderwelt des späten Mittelalters, in: Klaus Schreiner and Gabriela Signori (eds.), Bilder, Texte, Rituale. Wirklichkeitsbezug und Wirklichkeitskonstruktion politisch-rechtlicher Kommunikationsmedien in Stadt- und Adelsgesellschaften des späten Mittelalters, Zeitschrift für Historische Forschung, Beiheft 24 (Berlin, 2000) 139-164.

Simpson, James R., and Roach, Andrew (eds.), Heresy and the Making of European Culture: Medieval and Modern Perspectives (Farnham, 2013).

Sims-Williams, Nicholas, Some Reflections on Zoroastrianism in Sogdiana and Bactria, in: David Christian and Craig Benjamin (eds.), Realms of the Silk Roads: Ancient and Modern (Turnhout, 2000) 1-12.

Smail, Daniel L., The Consumption of Justice: Emotions, Publicity, and Legal Culture in Marseille, 1264-1423 (Ithaca, New York, 2003).

Snoek, Jan A. M., Religious Polemics in Context: An Annotated Bibliography, in: Hettema und van der Kooij, Religious Polemics in Context, 507-588.

Southcombe, George, Suerbaum, Almut and Thompson, Benjamin, Introduction, in: Suerbaum et al., Polemic, 1-14.

Soukup, Pavel, >Pars Machometicar in Early Hussite Polemics: The Use and Background of an Invective, in: Van Dussen and Soukup, Religious Controversy in Europe, 251-287.

Southern, Richard W., Western Views of Islam in the Middle Ages (Cambridge, Massachusetts, 1962).

Southern, Richard W., Medieval Humanism (New York, 1970).

Speer, Andreas, and Steinkrüger, Philipp (eds.), Knotenpunkt Byzanz: Wissensformen und kulturelle Wechselbeziehungen, Miscellanea Mediaevalia 36 (Berlin, 2012).

Stamm, Heinz-Meinolf, Luthers Stellung zum Ordensleben (Stuttgart, 1980).

Stauffer, Hermann, Polemik, in: Gerd Ueding (ed.), Historisches Wörterbuch der Rhetorik, Band 6: Must-Pop (Tübingen, 2003) 1403-1415.

Steckel, Sita, Falsche Heilige. Feindbilder des `Ketzers` in religiösen Debatten des Hoch- und Spätmittelalters, in: Harutyun Harutyunyan, Alfons Fürst, Eva-Maria Schrage and Verena Voigt (eds.), Von Ketzern und Terroristen: Interdisziplinäre Studien zur Konstruktion und Rezeption von Feindbildern (Münster, 2012) 17-44. 
Steckel, Sita, Professoren in Weltuntergangsstimmung. Religiöse Debatte und städtische Öffentlichkeit im Pariser Bettelordensstreit, 1252-1257, in: Jörg Oberste (ed.), Pluralität - Konkurrenz - Konflikt. Religiöse Spannungen im städtischen Raum der Vormoderne, Forum Mittelalter Studien 8 (Regensburg, 2013) 51-74.

Steckel, Sita, Ein brennendes Feuer in meiner Brust. Prophetische Autorschaft und polemische Autorisierungsstrategien Guillaumes de Saint-Amour im Pariser Bettelordensstreit (1256), in: Christel Meier and Martina Wagner-Egelhaaf (eds.), Prophetie und Autorschaft: Charisma, Heilsversprechen und Gefährdung (Berlin, 2014) 129-168.

Steckel, Sita, Une querelle des theologiens? The concept of "polemic « in the historiography of the secular-mendicant controversy, in: Sère, Les régimes de polémicité au Moyen Âge, forthcoming.

Steckel, Satirical Depictions of Monastic Life, in: Alison I. Beach and Isabel Cochelin (eds.), The Cambridge History of Western Monasticism (Cambridge, 2019) forthcoming.

Stenzel, Jürgen, Rhetorischer Manichäismus. Vorschläge zu einer Theorie der Polemik, in: A. Schöne, Kontroversen, alte und neue. Akten des VII. Internationalen GermanistenKongresses, Vol. 2 (Göttingen, 1985) 3-11.

Strauss, Leo, Persecution and the Art of Writing, (Glencoe, Illinois, 1952).

Strickland, Debra Higgs, Saracens, Demons and Jews. Making Monsters in Medieval Art (Princeton, 2003).

Stroumsa, Sarah, Thinkers of `This Peninsular: Toward an Integrative Approach to the Study of Philosophy in Al-Andalus, in: David M. Freidenreich und Miriam Goldstein (eds.), Beyond Religious Borders: Interaction and Intellectual Exchange in the Medieval Islamic World (Philadelphia, Pennsylvania, 2011) 44-56.

Stünkel, Knut Martin, Una sit religio: Religionsbegriffe und Begriffstopologien bei Cusanus, Llull und Maimonides (Würzburg, 2013).

Suchan, Monika, Mahnen und Regieren. Die Metapher des Hirten im früheren Mittelalter. Millennium-Studien/Millennium Studies 56 (Berlin, 2015).

Suerbaum, Almut, Southcombe, George and Thompson, Benjamin (eds.), Polemic: Language as Violence in Medieval and Early Modern Discourse (Farnham, 2015).

Symes, Carol, A Common Stage: Theater and Public Life in Medieval Arras, Conjunctions of Religion and Power in the Medieval Past (Ithaca, New York, 2007).

Szittya, Penn R., The Antifraternal Tradition in Medieval Literature (Princeton, 1986).

Szpiech, Ryan. Conversion and Narrative: Reading and Religious Authority in Medieval Polemic, The Middle Ages Series (Philadelphia, Pennsylvania, 2013).

Szpiech, Ryan (ed.), Medieval Exegesis and Religious Difference: Commentary, Conflict, and Community in the Premodern Mediterranean, Bordering Religions (New York, 2015).

Tang, Li and Winkler, Dietmar W. (eds.), From the Oxus River to the Chinese Shores: Studies on East Syriac Christianity in China and Central Asia, Orientalia - Patristica - Oecumenica 5 (Zürich, 2013).

Taylor, Joan E. (ed.), The Body in Biblical, Christian and Jewish Texts, The Library of Second Temple Studies 85 (London, 2014).

Thomas, David R. and Roggema, Barbara (eds.), Christian-Muslim Relations: A Bibliographical History, Vol. 1 (600-90o) (Leiden, 2009).

Thomas, David and Mallett, Alexander (eds.), Christian-Muslim Relations: A Bibliographical History, Vol. 2 (900-1050) (Leiden, 2010).

Thomas, David and Mallett, Alexander (eds.), Christian-Muslim Relations: A Bibliographical History, Vol. 3 (1050-1200) (Leiden, 2011). 
Thomas, David and Mallett, Alexander (eds.), Christian-Muslim Relations: A Bibliographical History, Vol. 4 (1200-1350) (Leiden, 2012).

Thomas, David and Mallett, Alexander (eds.) Christian-Muslim Relations: A Bibliographical History, Vol. 5 (1350-150o) (Leiden, 2013).

Thompson, Augustine, Lay Versus Clerical Perceptions of Heresy: Protests Against the Inquisition in Bologna, 1299, in: Praedicatores, Inquisitores 1: The Dominicans and the Medieval Inquisition, Acts of the First International Seminar on the Dominicans and the Inquisition. 2325 February 2002, Institutum Historicum Fratrum Praedicatorum Romae Dissertationes Historicae 39 (Rome, 2004) 701-730.

Thompson, Benjamin, The Polemic of Reform in the Later Medieval English Church, in: Suerbaum et al., Polemic, 183-222.

Thum, Bernd, Öffentlichkeit und Kommunikation im Mittelalter. Zur Herstellung von Öffentlichkeit im Bezugsfeld elementarer Kommunikationsformen im 13. Jahrhundert, in: Hedda Ragotzky and Horst Wenzel (ed.), Höfische Repräsentation. Das Zeremoniell und die Zeichen (Berlin, 1990) 65-87.

Till, Dietmar, Text, Kommunikation und Affekt in der Tradition der Rhetorik. Zur Vorgeschichte des `Emotional turn`, Mitteilungen des Deutschen Germanistenverbandes 54/3 (2007) 286-305.

Tischler, Matthias M., and Fidora, Alexander (eds.), Christlicher Norden, Muslimischer Süden: Ansprüche und Wirklichkeiten von Christen, Juden und Muslimen auf der Iberischen Halbinsel im Hoch- und Spätmittelalter, Erudiri Sapientia 7 (Münster, 2011).

Tischler, Matthias M., "Lex Mahometi«. The Authority of a Pattern of Religious Polemics, Journal of Transcultural Medieval Studies 2 (2015) 3-63.

Tolan, John V., Sons of Ishmael: Muslims through European Eyes in the Middle Ages (Gainesville, 2008).

Tolan, John V., Saracens: Islam in the Medieval European Imagination (New York, 2013).

Tolan, John V. and El Anabi, Hassen (eds.), Identités en mutation. L'Europe et le bassin méditerranéen (Frankfurt, 2013).

Tolan, John V., Veinstein, Gilles and Laurens, Henry (eds.), Europe and the Islamic World: A History, translated by Jane Marie Todd (Princeton, 2013).

Tolan, John V., Nicholas De Lang, Capucine Nemo-Pekelman, Laurence Foschia (eds.), Jews in Early Christian Law: Byzantium and the Latin West, 6th-11th Centuries, Religion and Law in Medieval Christian and Muslim Societies 2 (Turnhout, 2014).

Tolan, John V., and Boisselier, Stéphane (eds.), Religious Cohabitation in European Towns (10th -15th Centuries)/La cohabitation religieuse dans les villes européennes, Xe-Xve siècles, Religion and Law in Medieval Christian and Muslim Societies 3 (Turnhout, 2014).

Tomasch, Sylvia, Postcolonial Chaucer and the Virtual Jew, in: Cohen, Postcolonial Middle Ages, 243-260.

Trautner-Kromann, Hanne, Shield and Sword: Jewish Polemics against Christianity and the Christians in France and Spain from 1100-1500, Texts and Studies in Medieval and Early Modern Judaism 8 (Tübingen, 1993).

Trivellone, Alessia, L'hérétique imagine. Hétérodoxie et iconographie dans l'Occident médiéval de l'époque carolingienne à l'Inquisition, Collection d'études médiévales de Nice 10 (Turnhout, 2009).

Utz-Tremp, Kathrin, Von der Häresie zur Hexerei. »Wirkliche« und imaginäre Sekten im Spätmittelalter, MGH Schriften 59 (Hannover, 2008). 
Van Dussen, Michael and Soukup, Pavel (eds.), Religious Controversy in Europe, 1378-1536: Textual Transmission and Networks of Readership, Medieval Church Studies 27 (Turnhout, 2013).

Van der Wall, Ernestine, Ways of Polemicizing: The Power of Tradition in Christian Polemics, in: Hettema and van der Kooij, Religious Polemics in Context, 401-414.

Van Renswoude, Irene and Baumgartner, Christoph, Censorsphip, Free Speech and Religion, in: Paul Hedges (ed.), Controversies in Contemporary Religion: Education, Law, Politics, Society, and Spirituality (Santa Barbara, 2014) 123-151.

Von Karajan, Theodor, Buch der Rügen, Zeitschrift für deutsches Altertum 2 (1842) 6-92.

Von Mutius, Hans-Georg, Rechtsentscheide Raschis von Troyes (1040-1105). Quellen über die sozialen und wirtschaftlichen Beziehungen zwischen Juden und Christen, Judentum und Umwelt 15, 2 vols. (Frankfurt am Main, 1986/1987).

Von Stuckrad, Kocku, Religionsvergleich, in: Friedrich Jaeger (ed.), Enzyklopädie der Neuzeit Online. Retrieved on 22 September 2017: dx.doi.org/10.1163/2352-0248_edn_a3602000.

Walsham, Alexandra, Migrations of the Holy: Explaining Religious Change in Medieval and Early Modern Europe, Journal of Medieval and Early Modern Studies 44/2 (2014) 241-80.

Weijers, Olga, Queritur utrum: Recherches sur la "disputatio" dans les universités médiévales, Studia artistarum 20 (Turnhout, 2009).

Weiler, Björn, Clerical admonitio, Letters of Advice to Kings, and Episcopal Self-Fashioning, c. 1000-c. 1200, History 102/352 (2017) 557-575.

Weltecke, Dorothea, Über Religion vor der `Religion`. Konzeptionen vor der Entstehung des neuzeitlichen Begriffs, in: Thomas G. Kirsch, Rudolf Schlögl and Dorothea Weltecke (eds.), Religion als Prozess. Kulturwissenschaftliche Wege der Religionsforschung (Paderborn, 2015) 13-34.

Weltecke, Dorothea, Space, Entanglement and Decentralisation: On How to Narrate the Transcultural History of Christianity (550 to $1350 \mathrm{CE}$ ), in: Reinhold Glei and Nikolas Jaspert (eds.), Locating Religions: Contact, Diversity, and Translocality, Dynamics in the History of Religions 9 (Leiden, 2017) 315-344.

White, Steven D., The Feelings in the Feud: The Emotional Turn in the Study of Medieval Vengeance, in: Kim Esmark, Lars Hermanson, Hans Jacob Orning and Helle Vogt (eds.), Disputing Strategies in Medieval Scandinavia, Medieval Law and Its Practice 16 (Leiden, 2013) 281-312.

Wiedl, Birgit, Laughing at the Beast: The Judensau. Anti-Jewish Propaganda and Humor from the Middle Ages to the Early Modern Period, in: Albrecht Classen (ed.), Laughter in the Middle Ages and Early Modern Times, Fundamentals of Medieval and Early Modern Culture 5 (Berlin, 2010) 325-364.

Wiegers, Gerard, Fuzzy Categories and Religious Polemics: The Daily Life of Christians and Muslims in the Medieval and Early Modern Mediterranean World, Common Knowledge 19/3 (2013) 474-489.

Wilson, M. Brett, The Failure of Nomenclature: The Concept of `Orthodoxy` in the Study of Islam, Comparative Islamic Studies 3/2 (2007) 169-194.

Wohlfeil, Rainer, >Reformatorische Öffentlichkeit`, in: Karl Stackmann and Ludger Grenzmann (eds.), Literatur und Laienbildung im Spätmittelalter und in der Reformationszeit. Symposion Wolfenbüttel 1981, Germanistische Symposien - Berichtsbände 5 (Stuttgart, 1984) 41-54.

Yuval, Israel Jacob, Pessach und Ostern: Dialog und Polemik in Spätantike und Mittelalter (Trier, 1999). 
Yuval, Israel Jacob, Zwei Völker in deinem Leib. Gegenseitige Wahrnehmung von Juden und Christen in Spätantike und Mittelalter, translated by Dafna Mach, Jüdische Religion, Geschichte und Kultur 4 (Göttingen, 2007).

Yuval, Israel Jacob, and Ben-Shalom, Ram (eds.), Conflict and Religious Conversation in Latin Christendom: Studies in Honour of Ora Limor, Cultural Encounters in Late Antiquity and the Middle Ages 17 (Turnhout, 2014).

Zellentin, Holger M., Rabbinic Parodies of Jewish and Christian Literature, Texte und Studien zum antiken Judentum /Texts and Studies in Ancient Judaism 139 (Tübingen, 2011).

Zürcher, Erich, The Buddhist Conquest of China: The Spread and Adaptation of Buddhism in Early Medieval China, Sinica Leidensia 11 (third edition) (Leiden, 2007). 